Review

\title{
Reviewing the Anaerobic Digestion of Food Waste: From Waste Generation and Anaerobic Process to Its Perspectives
}

\author{
Carlos Morales-Polo *(D), María del Mar Cledera-Castro and B. Yolanda Moratilla Soria \\ ICAI School of Engineering, Comillas Pontificial University, Alberto Aguilera 25, 28015 Madrid, Spain; \\ mcledera@comillas.edu (M.d.M.C.-C.); y.moratilla@comillas.edu (B.Y.M.S.) \\ * Correspondence: cmorales@comillas.edu; Tel.: +34-91-542-28-00
}

Received: 31 August 2018; Accepted: 26 September 2018; Published: 2 October 2018

\begin{abstract}
Discharge of waste in general, and food waste, in particular, is considered one of the major environmental problems today, as waste generation increases continuously, reaching values of $32 \%$ of all food produced worldwide. There are many different options that can be applied to the management and evaluation of waste treatment, and Anaerobic Digestion seems to be one of the most suitable solutions because of its benefits, including renewable energy generation in form of biogas. Moreover, if FW (food waste) is digested in anaerobic digesters from Waste Water Treatment Plants, a common solution is provided for both residues. Furthermore, co-digestion of food waste and sewage sludge provides benefits in terms of anaerobic process stability enhancing the buffer capacity of ammonia (for example) and biogas formation, which can be increased up to $80 \%$ when compared with monodigestion. The present paper reviews food waste anaerobic digestion from its generation, characteristics and different options for its management, and it does focus specifically on the anaerobic digestion and co-digestion process, stages, limiting rates and parameters, utilizing numerous experiences, strictly related to food waste. Pre-treatments are also considered as they are important and innovative for enhancing biogas production and its methane yield. The paper shows an extensive collection of pre-treatments, its basics, improving factors, and numerical data of biogas formation improvements that are related both to substrate modification and to the synergistic effect of co-digestion, which could lead to an increase of methane production from $11 \%$ to $180 \%$.
\end{abstract}

Keywords: food waste characterization; bioenergy; biogas; methane yield; hydrolysis; pre-treatments; perspectives

\section{Introduction}

Materials, intended or not, for human consumption that are discharged, lost, degraded, contaminated, or eliminated from the food supply chain (FSC), as well as the previous or forward stages and operations are known as food loss (FL) and food waste (FW) [1]. According to the Food and Agriculture Organisation of the United Nations (FAO) [2], FL is defined as any kind of change in the availability, or the quality of edible material that prevents it from being consumed by people. Due to this, food waste can be a consequence of FL.

Traditionally, FW was considered as the FL accrued at the retail and final consumption stages, so its generation is relegated to retailer and consumer behaviour [3]. Nowadays, the definition of FW also includes the losses incurred in the FSC stages or any other step of the agri-food industry, therefore it is defined as "any food and inedible parts of food, removed from (lost to or diverted form) the food supply chain to be recovered or disposed (including composted, crops ploughed in/not harvested, anaerobic digestion, bio-energy production, co-generation, incineration, disposal to sewer, landfill or discarded to sea". 
The FSC begins, in any case, with the agricultural sector (farming) that produces by-product (i.e., manure, waffle, cornstalk) and FW and FL in the form of low quality products, damaged production, or products with no commercial value. Adequate products are used by the processing and manufacturing industry, where FL and FW are mainly generated within the entire process chain due to problems in storage, damages during transport, contamination along the process, or in separation stages that create by-products not intended for human consumption (i.e., feathers, skins, fruit peels ... ) [4]. In the case of food markets and retail systems, FL and FW is generated in association with problems in storage, conservation, or unsold perishable products [3]. At the final stage of the product live cycle (end consumer), the FW is generated by a purchasing excess, over preparation processes, bad storage conditions, and other consumption behaviour patterns.

It is estimated that around a 33\% of all food produced worldwide is wasted globally in form of FW and FL [5,6]. Particularly the European Union (EU), 90 million tons of FW are generated annually [7]. That means that each European Citizen produces $76 \mathrm{~kg}$ of FW per year [8] only at household level, but if all the FSC is considered, then this number does increase up to $179 \mathrm{~kg}$ of FW and FL per capita [9]. This kind of waste production represents $12 \%$ of all the food entering a home [10], and a $25 \%$ of all the food of the FSC. This implies that within the complete FSC, $40 \%$ of FW, and FL occurs during postharvest and processing stages and another $40 \%$ during the retail and consumer levels.

The generation of FW effectuates an impact in social, economic, and environmental spheres [1]. The most remarkable effects are environmental: for example, soil depletion due to landfill saturation, or the ground needs for agricultural raw materials and the consequent soil contamination. FW and FL also contribute to emissions of Green House Effect gases in transportation, storage and distribution operations, in landfill disposal due to methane emissions, or other disposal operations, such as incineration [11]. Social effects are related with ethical behaviours in terms of excessive resource consumption, and economic impacts may be ascribed to the costs that are related to food waste. Meaning that waste treatment methods for FW are currently evaluated, not only according to their treatment efficiency, but also in their environmental and social impacts [12]. Life cycle assessment seems to be a perfectly fitted tool for evaluating this determinants, especially environmental ones [13,14], such as carbon print, or its influence in climate change [15].

In this context, many legislative instruments arise to minimize the impact of FW. The Environmental Protection Agency (EPA) [16] defines a hierarchy in FW management: (a) Source reduction, (b) feed hungry people, (c) feed animals, (d) industrial uses, (e) composting, and (f) incineration or landfilling.

In the context of the EU, already in 1995 the Council Directive 1999/31/EC of 26 April 1999 on the landfill of waste [17] was launched, with the objective for 2016: "not later than 15 years after the date laid down in Article 18(1), biodegradable municipal waste going to landfills must be reduced to 35\% of the total amount (by weight) of biodegradable municipal waste produced in 1995 or the later year before 1995 for which standardised Eurostat data is available".

As a follow-up on the Council Directive 1999/33/CE [17], the DIRECTIVE 2008/98/EC OF THE EUROPEAN PARLIAMENT AND OF THE COUNCIL, of 19 November 2008, on waste and repealing certain Directives [18] has the scope of establishing "measures to protect the environment and human health by preventing or reducing the adverse impacts of the generation and management of waste and by reducing overall impacts of resource use and improving the efficiency of such use". According to this, a waste hierarchy has been established in waste management: (a) prevention; (b) preparing for re-use;(c) recycling; (d) other recovery, e.g., energy recovery; and (e) disposal, as shown in Figure 1. This hierarchy must be followed, both by consumers $(a, b)$ and by waste managers (c, $d$ and e) $[18,19]$.

Some remarkable objectives for 2020, set in this directive, are:

"by 2020, the preparing for re-use and the recycling of waste materials [... ], shall be increased to a minimum of overall $50 \%$ by weight".

"by 2020, the preparing for re-use, recycling and other material recovery, [ . . ] shall be increased to a minimum of $70 \%$ by weight". 


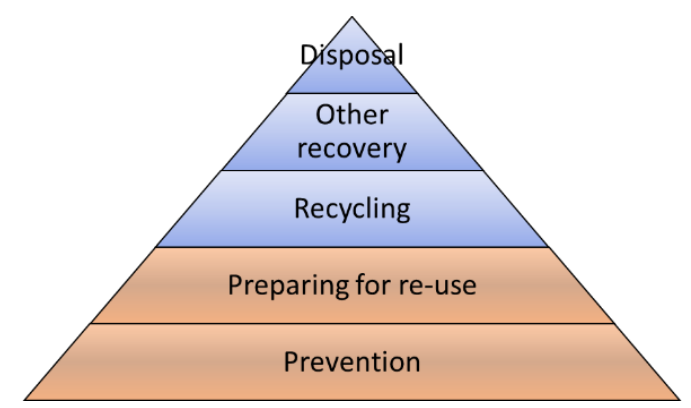

Figure 1. Waste management hierarchy according to Council Directive 1999/33/CE [17].

Due to the above, the main scope around those legal instruments is to progressively change the traditional point of view from residues as "waste to eliminate", to perceive them as a new resource for other uses, including industrial ones. FW can be utilized for production of highly valued materials such as biodegradable plastics, enzymes, and organic acids [20]. It can be also used for developing value-added bioproducts [21], such as methane [22-24], biopolymers and organic acids [25-27], ethanol [22,28,29], and hydrogen [30,31]. Energy and fuel applications are the ones creating more added value, along with animal feed and electricity generation [32], to be composed of ethanol, hydrogen, methane, and biodiesel.

Anaerobic Digestion (AD) is a process enabling the creation of biogas (methane-rich gas) via microbiological digestion of the organic fraction of residues in anaerobic conditions (FW in this case). The result of the anaerobic digestion, known as digestate, can be treated as a residue (with a smaller volume), or as a by-product to be used as an agricultural fertilizer. AD process represents a way of recycling, recovery (in form of energy and industrial use as fertilizer), and a reduction system of landfill disposal; partial if digestate is eliminated, or complete if digestate is re-used [4,33]. In addition to prevention and the preparation for reuse, obligations for generators and citizens, AD is a process that accomplishes all of the steps of the European Waste Hierarchy, previously shown in Figure 1.

In light of this, $\mathrm{AD}$ is one of the most remarkable and adequate solutions for recovering residues. This paper is intended to review in general terms the recovery of FW and in particular, the AD process as a biofuel or energetic recovery in form of biogas, the anaerobic process, its characteristics, and factors implicated in biogas production. Furthermore, experiences with anaerobic digestion and co-digestion are reviewed, along with pre-treatments to enhance biogas production.

\section{FW Characterisation}

Characteristics and composition of FW strongly depends on where in the process the non-edible and non-usable materials are generated. FW generated in the first part (agriculture and livestock) are mainly composed of non-edible materials, separated from feedstocks. They are completely different in composition from FW generated in the final step of food supply chain (markets), where other material fractions are included, such as glass, metals, paper, plastics, and so forth, which stem from packaging. In the case of FW generated by the consumers, its composition depends strongly on different eating and cooking habits [34].

For those reasons, many researchers had characterised FW, each one with its own compositions and characteristics, depending on its origin, geographical location, social behaviours, habits, and local products... [35].

From the point of view of $\mathrm{AD}$ and waste reuse, it is important to thresh the composition regarding organic components like lipids, proteins, and carbohydrates (LPCH) and volatile fatty acids (VFA), content of total solids (TS) and volatile solids (VS), nitrogen content (N), carbon content (C), and its ratio (N/C). A review of FW characteristics and composition is provided in Table 1. 
Table 1. Food waste composition reported by various authors.

\begin{tabular}{|c|c|c|c|c|c|c|c|c|c|c|}
\hline \multicolumn{11}{|c|}{ Food Waste Composition } \\
\hline FW Type and Origin & \multirow[t]{2}{*}{ TS [\%] } & \multirow[t]{2}{*}{ VS [\%] } & \multirow[t]{2}{*}{ Proteins [\%] } & Lipids [\%] & Carbohydrates [\%] & \multirow[t]{2}{*}{ VFA [\%] } & \multirow[t]{2}{*}{$\mathrm{C}[\%]$} & \multirow[t]{2}{*}{$\mathbf{N}[\%]$} & \multirow[t]{2}{*}{ C/N Ratio } & \multirow{2}{*}{$\begin{array}{c}\text { Reference } \\
{[36]}\end{array}$} \\
\hline Household individual sorted materials & & & & & & & & & & \\
\hline Meat and bone & & & $70-75$ & $23-30$ & 1 & & & & & [37] \\
\hline Fish and fishbone & & & 75.6 & 20.2 & & & & & & [38] \\
\hline Egg and shell & & & 35 & 32 & 2 & & & & & [39] \\
\hline Dairy products & & & $25-35$ & $20-45$ & 53 & & & & & [39] \\
\hline Fruit & & & 4 & 2 & 83 & & & & & [40] \\
\hline Vegetable & & & 27 & 1.4 & 27 & & & & & [41] \\
\hline \multicolumn{11}{|l|}{ Individual fractions from OFMSC } \\
\hline Animal kitchen waste & & 33.3 & 54.4 & 35.7 & 9.9 & & & & & \\
\hline Vegetable kitchen waste & & 13.4 & 21.6 & 19.4 & 57.6 & & & & & [42] \\
\hline Raw animal waste & & 38.6 & 59.8 & 27.2 & 13 & & & & & \\
\hline Raw vegetable waste & & 10.8 & 19.4 & 11.1 & 69.4 & & & & & \\
\hline OFMSC in Sweden & & 90.8 & 18.2 & 20 & 29.4 & 0.35 & 50 & 2.8 & 17.85 & [43] \\
\hline \multicolumn{10}{|l|}{ Fractions of OFMSC in Denmark } & \multirow{3}{*}{ [44] } \\
\hline Animal food waste & 41 & 84 & 12 & 25 & $52^{\mathrm{a}}$ & & & & & \\
\hline Vegetable food waste & 24 & 93 & 5 & 14 & $53^{\mathrm{a}}$ & & & & & \\
\hline Food waste & & 29.3 & 26.6 & 35 & 32.5 & & 48.4 & 3.8 & 12.7 & [45] \\
\hline Food waste & 18.1 & 17.1 & & 23.3 & 61.9 & & & & & [46] \\
\hline Food waste & 23.1 & 21.0 & & & & & 56.1 & 2.3 & 24.5 & [47] \\
\hline Food waste for AD & 30.9 & 26.35 & & & & & 46.8 & 3.54 & 13.2 & [48] \\
\hline Kitchen waste & 24 & 23.2 & 15 & 23.9 & 55.2 & & 54 & 2.4 & 22.5 & [49] \\
\hline Food waste & 23.2 & 21.7 & 2.9 & 6.5 & 13.7 & & & & & [50] \\
\hline OFMSC from municipal biowaste & 20 & 18 & 30 & 4.4 & 10.7 & & & & 17 & [51] \\
\hline Food waste & 16.7 & 15.3 & 2.4 & 1.4 & & & & & 11.5 & [52] \\
\hline \multicolumn{11}{|l|}{ Notes ${ }^{a}$ : Only easily-degradable carbohydrates } \\
\hline \multicolumn{11}{|c|}{ Metal Elements in FW [g/kg-TS] } \\
\hline $\mathrm{Ca}$ & $\mathrm{Mg}$ & $\mathbf{K}$ & $\mathrm{Na}$ & $\mathrm{Zn}$ & Mn & Mo & & & Reference & \\
\hline Food waste & 0.7 & 9.6 & 10.1 & 0.032 & 0.005 & 0.00003 & & & [45] & \\
\hline
\end{tabular}


Whilst the composition in terms of carbohydrates, lipids and proteins gives an overall idea of the composition, together with the solids content, a more extensive characterisation in terms of carbon content or nitrogen is necessary to finally differentiate them.

From the elemental composition, some conclusions arise, such as the suitability of FW for degradation processes, like $\mathrm{AD}$, due to its high carbon content and moisture level, indicating that water accounts for $70-80 \%$ [34].

\section{Industrial uses of FW, Different from Anaerobic Digestion}

Giving added value to residues creates a circular economy benefitial to all the sectors that are involved in raw materials, products, waste management, and potential users of the new bioproducts. In the case of FW, the entire economic sector achieves benefits from circular economy: Primary sector (farming, agriculture ... ), secondary sector (If residues are intended for producing biomaterials), and tertiary sector (markets and retail facilities).

\subsection{Biomaterials Production}

From organic waste, and especially from FW, biopolymers can be produced [53] by obtaining the necessary monomers through the fermentation of carbohydrate feedstocks by microbes [54]. These biopolymers are a suitable option for substituting petrochemical products, as they have similar properties and they ensure biodegradability [55].

Examples of these biopolymers are polylactate, a plastic constituent obtained from lactate and lactic acid, polyhydroxyalkanotes, such as polyhydroxybutyrate, with characteristics that are similar to polypropylene and polyethylene, and succinate, which can be used for plastic and detergent production [56,57].

Recent research shows that biopolymers production from FW could be implemented with bioenergy production when combining anaerobic and aerobic processes. In this case, part of the volatile fatty acids from the anaerobic process can be transformed into polyhydroxyalkanoates, combining both biogas and biopolymers production [58].

\subsection{Energy Production}

Biodiesel, which is fuel suitable for diesel engines, is defined as fatty acid alkyl esters of long-chain fatty acids and short-chain alcohols, derived from natural oils (either animal or vegetable origin) or any fatty acid [59], and obtained by transesterification. Biodiesel in growing interest as any kind of fatty acid source is suitable for transesterification. On the one hand, edible oils are a good option for biodiesel products, but, on the other hand, they have been questioned due to the competition against food materials (food vs. fuel) [60-62]. Therefore, the most efficient element for biodiesel production are non-edible or waste oils [63], such as recycled frying oils, as representation of food waste [64,65] Those oils can be treated solely or co-treated, as occurs with substrates for anaerobic digestion [66]. In this case, fats from slaughterhouses or other industrial oils $[67,68]$ are a clever solution.

Bioethanol can be defined as a bioalcohol, which is obtained from the fermentation of carbohydrates from sugar-rich elements. Bioethanol can be used as fuel in gasoline engines (Otto cycle engines). Feedstocks for first generation ethanol are food crops (starch, sugar wheat, or corns crops), which have to compete with food generation against food vs. fuel dilemma. This can be overcome with second generation bioethanol, more readily accepted due to the use of non-edible materials such as feedstocks, including food waste and agricultural waste, which are considered a renewable and abundant source. Fruit waste is the most representative feedstock for second generation bioethanol on account of its high carbohydrate content. Pre-treatments are commonly used to improve the saccharification and the final fermentation process of the substrates [69].

If FW or other substrate is treated in a fermentation process using Clostridium acetobutylicum bacteria, biobutanol is obtained as an alternative to bioethanol. It has several advantages as compared 
with it, represented by a lower vapour pressure and improved combustion efficiency. It can also be dissolved with any other oil to reduce its viscosity [70].

Incineration is, surely, one of the most mature technologies, consisting in the complete combustion of residues, to reduce its volume into organic ashes and utilize the released heat for energy production. Despite this, FW is not so suitable for this technology and its utilization is limited due to its high moisture and water content [44], together with air emissions from combustion, facing the environmental indicators [71].

As other thermal processes, alternatives to combustion, pyrolysis, and gasification can be mentioned. On one side, pyrolysis converts FW from solid state into liquid (pyrolysis oil) or gas (syngas) [1,71], products that can be used as fuel or raw materials for chemical processes, through the effect of temperature $\left(400-800^{\circ} \mathrm{C}\right)$. The carbon residues resulting from pyrolysis can be refined to obtain activated carbon or other carbonated products. On the other side, gasification oxidises FW by means of high temperatures $\left(800-900{ }^{\circ} \mathrm{C}\right)$, to produce synthesis gas, a gas mixture that can be used directly as fuel in combustion processes, or as input in chemical production processes, to obtain methanol, for example, among other products.

The applicability of these thermal processes depends strongly on waste characteristics and composition, so FW has to be pre-treated before its conversion into pyrolysis oil, syngas, or gasification [71,72]. Specifically, water content seems to be the most limiting characteristic for thermal processes. Some processes independent from water content are Hydrothermal Carbonization (HTC) and Hydrothermal Gasification (HTG). On one hand, HTC is used to convert FW, or other materials, into a valuable energy resource known as hydrochar [73], with high carbon content and energy potential. On the other hand, HTG can generate hydrogen gas from biowaste, such as FW, especially the carbohydrate rich ones [74].

$\mathrm{AD}$ is a well-established technology that enables the transformation of any biodegradable residue, especially FW, into biogas (a rich methane gas mixture) [75]. This technology is perfectly suited for any part of the FW chain and can be applied to all kinds of biodegradable waste, such as organic fraction of municipal solid waste (OFMSW), agricultural waste, industrial waste, food waste, and so on. It is considered to be a flexible process that can be used as the final conversion process in most industries, giving added value to those non-convertible residual flows. This is why interest in AD has been continuously growing and has been promoted by many national energetic programmes $[75,76]$.

$\mathrm{AD}$ can be used for biogas production, but it is also considered to be a good option for hydrogen production, as it is released in one of the stages of the anaerobic fermentation process [36].

\section{Anaerobic Digestion of Food Waste}

AD study and applications have been growing in the last decades [48,71,77-81], for many reasons, especially its suitability to treat any kind of biodegradable residue like FW or municipal waste, and the needs for renewable energy generation and other waste destinations that are different from landfilling [33].

FW is perfectly suitable for AD [82] because of its composition and moisture content. In general, terms, carbohydrates and proteins are traduced in a common biogas yield with faster transformation. On the contrary, lipids present a slower biodegradability development, but they provide a higher level and quality of biogas $[83,84]$. Therefore, it is important to understand the mechanism of AD process and all of the reactions involved.

\subsection{AD Process}

During the anaerobic degradation process, the OM content of FW (or any substrate) is transformed into biogas in a chain process that includes mainly four consecutive steps [85]. These four reactions are (a) hydrolysis, (b) acidogenesis, (c) acetogenesis, and (d) methanogenesis [86]. Figure 2 shows two different and complete schemes of AD reactions and development. 


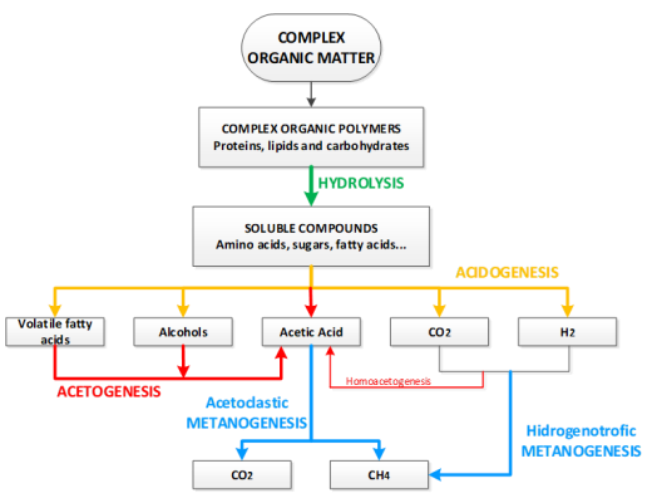

(a)

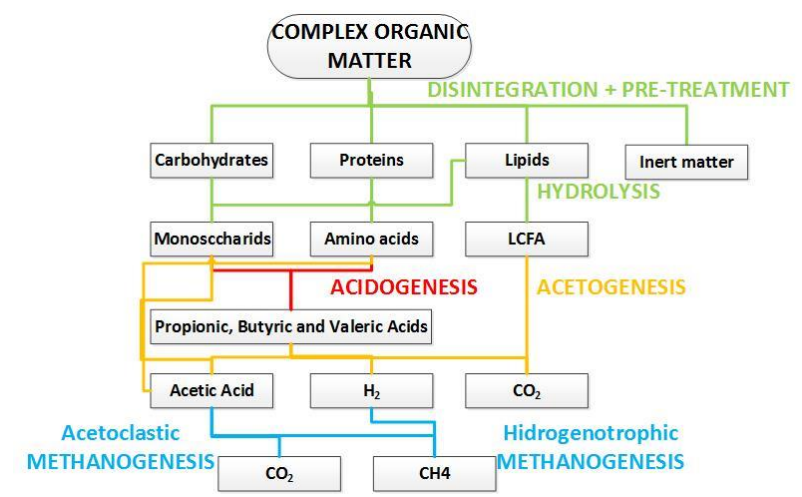

(b)

Figure 2. Anaerobic digestion process and reactions. (a) Simplified way and (b) adapted from [75] for ADM1 Simulation.

The process is carried out by numerous microbiological species and different bacteria working through syntropy (the growth of one partner is improved, or depends on the nutrients, growth factors, or substrate provided by the other partner). This means the positive development of the process is related to a correct balance of bacterial populations. Some bacteria that are associated to hydrolysis are capable of degrading the OM either in aerobic or anaerobic conditions. That is why they are named facultative bacteria. Otherwise, bacteria that are responsible for the other reactions are strictly anaerobic [87].

To completely degrade OM from substrates, present as lipids, carbohydrates, and proteins (organic polymers), it has to firstly be hydrolysed in order to reduce those macromolecules and transform them into other soluble compounds such as aminoacids, sugars and long chain fatty acids. This process is known as hydrolysis, an extracellular reaction carried out by enzymes that should be primarily adsorbed on the surface of solid substrates $[88,89]$. This is the reason why hydrolysis is considered the stage-limitng step for AD development.

Secondly, the small molecular materials created during hydrolysis are converted during the acidogenesis phase into volatile fatty acids (acetic, propionic, and butyric acids), and other by-products, like $\mathrm{NH}_{3}, \mathrm{CO}_{2}$, and $\mathrm{H}_{2}$ gases, and small parts of alcohols, aldehydes, and ketones. Acetogenesis is an intracellular reaction (as all the following reactions are) that is carried out by fermenting bacteria.

Thirdly, products obtained in the previous reactions are transformed into acetate, $\mathrm{H}_{2}$, and $\mathrm{CO}_{2}$ during the acetogenesis phase through acetogenic bacteria. These ones are suitable applicants to be transformed into methane and carbon dioxide, among other gases that constitute biogas.

Finally, in the methanogenesis phase, methanogens transform short-chain fatty acids, alcohols, and gases $\left(\mathrm{CO}, \mathrm{CO}_{2}\right.$, and $\left.\mathrm{H}_{2}\right)$ into methane $\left(\mathrm{CH}_{4}\right)$. This can occur via acetoclastic methanogenesis or hydrogenotrophic methanogenesis. In the first case, acetoclastic methanogens mainly use acetate to form methane, whilst hydrogenotrophinc methanogens use $\mathrm{H}_{2}$ and $\mathrm{CO}_{2}$. In addition, carbinol and $\mathrm{CO}$ can be also transformed into methane [34]. All of these reactions are shown in Figure 2.

During methanogenesis, a large number of intermediate products are formed by a unique bacteria population. It is an extremely complex process: on one hand, it uses a reduced substrate group, and, on the other hand, methanogens are the most strictly anaerobic microorganisms (methanogens growth only occurs under a red-ox potential below $-330 \mathrm{mV}$ ).

In general terms, reference [90] states that carbohydrates are degraded into saccharides and sugars to produce VFA, alcohols, and organic acids. Lipids are degraded into glycerol, glycerine, and long-chain fatty acids, to further be transformed into VFA. Proteins, which are mainly considered as the encapsulation of nitrogen, are transformed from peptides to amino acids, and finally into VFA.

$\mathrm{AD}$ is an extremely complex process that should simultaneously digest all substrates in order to produce the substrate for the next phase reaction. This requires a stable environment for the different 
microbial growth. It is therefore important to maintain the key parameters of AD process within the correct range, to ensure the appropriate operation of $\mathrm{AD}$.

\subsubsection{Hydrolysis as Stage-Limiting and Rate-Limiting Reaction in AD}

When a process develops as a result of various chain reactions, as in the case of AD, generally one step has a slower development and, consequently, is considered as the limiting stage of the process $[91,92]$. In the AD process, hydrolysis is considered to be the stage-limiting process, being closely linked to substrate nature, its particle size, temperature, $\mathrm{pH}$, and organic load [93], as it is the first stage of the process. A good contact or interaction between substrate and inoculum is required for a correct hydrolysis development [45] to enable enzymes in developing the extracellular reaction through adsorption on the surface of particle substrate [94]. Moreover, a correct evolution of hydrolysis, if surface area that is available for bacteria is sufficient, results in a better and significant development of further reactions (acidogenesis, acetogenesis, and methanogenesis) and subsequently in more biogas production [95-97]. This results in hydrolysis as stage-limiting and rate-limiting, as it is responsible for developing the subsequent reactions and enhancing biogas production [98-100].

Most organic matter is present in the form of particulate organic matter (POM), especially FW. During hydrolysis, particulate compounds are transformed into monomeric or dimeric soluble substrates, which can be incorporated into the cells for its methanation. Thus, in the case of organic matter, hydrolysis not only comprises classic hydrolysis of Organic Matter (OM) polymeric material, in the shape of lipids, proteins and carbohydrates (LPCH). Other transformation processes should also be reported (enzymatic or not) to transform the particulate matter into accessible polymeric compounds and expose the maximum contact surface for enzymes to act upon. Therefore, hydrolysis can be disaggregated into two different processes, (a.1) "disintegration" of POM into lipids, proteins, and carbohydrates, and (a.2) the proper enzymatic hydrolysis of LPCH [101]. As these two stages take place simultaneously and they are impossible to decouple, they are commonly included within a unique kinetics reaction. Meaning that, on a practical level, hydrolysis of POM and its rate is defined as the rate at which the POM is converted into assimilable substrate for anaerobic archaea. Parameters influencing hydrolysis and hydrolysis rate are mainly (a) temperature, (b) $\mathrm{pH}$, (c) substrate structure, and (d) particle size.

Temperature and $\mathrm{pH}$

Temperature's global effect on hydrolysis is originated by the combination of enzymatic kinetics, bacterial growth, and substrate solubility effect on improved activity [94]. There has been a lot of effort to determine the kinetic constants of anaerobic treatment [102-104], which are typically considered a first order kinetics that increases with temperature [89].

First order kinetics variations are commonly estimated by Arrhenius equation:

$$
k=A \cdot e^{\frac{-\Delta G^{*}}{R \cdot T}}
$$

where " $\mathrm{k}$ " represents kinetic constants (hydrolysis constant in this case), " $A$ " Arrhenius constant, “G" $G$ " and " $R$ " standard activation energy and perfect gases constant, expressed in $\frac{J}{m o l}$ and $\frac{J}{m o l-K}$, respectively, and finally, " $T$ " represents the process temperature measured in absolute temperature [K].

For its part, $\mathrm{pH}$ has a complex feature, similar to the global AD process, as many different enzymes intervene in hydrolysis, each one with a different optimum $\mathrm{pH}$ for its growth. Net $\mathrm{pH}$ effect in hydrolysis is determined by the optimum $\mathrm{pH}$ for the different enrolled enzymes [99].

\section{Substrate Structure}

Substrate structure and its accessibility for hydrolytic enzymes is a key parameter, as a dissolved substrate is easier to hydrolyse, as compared with a particle substrate [87]. Substrate accessibility can be modified by forming complexes with other compounds. As an example, proteins can be affected 
by humic acids [105]. Likewise, cellulose is readily biodegradable, and, when mixed with lignine, its degradability can be reduced by up to $25 \%$ [106]. Another example could be particulate matter with a porous texture and with a chemical composition dominated by simple carbohydrate, such as fruit waste, which can be easily disintegrated in water, thus resulting in immediate availability to microorganisms [107].

\section{Particle Size}

Particle size is directly linked with substrate contact surface $[95,108]$. While particle size increases, the contact surface is reduced and the available space for enzymes is minimized, meaning that in an hydrolytic enzyme excess, particle size can be a limiting factor [109]. A good contact between substrate and inoculum in $\mathrm{AD}$ is necessary, as enzymatic processes are extracellular reactions and they are benefited by adsorption to a particulate surface $[45,92]$. Smaller particles with higher surface area will present higher reaction efficiency during $\mathrm{AD}$, and consequently biogas yield is increased [110]. Nevertheless, reducing particle size can improve hydrolysis development, and an excessive reduction can result in the over-stimulation of hydrolysis and consequently of acidogenesis with high production of VFA and ammonia, both process inhibitors [107,111].

\subsection{Key Parameters}

\subsubsection{Temperature}

Temperature is one of the most significant parameters, as it influences the activity of enzymes and co-enzymes responsible for hydrolysis development, methane yield, and digestate quality $[88,89,112]$. Anaerobic microbes and bacteria can grow in psychrophilic $\left(10-30^{\circ} \mathrm{C}\right)$, mesophilic $\left(30-40^{\circ} \mathrm{C}\right)$, and thermophilic $\left(50-70{ }^{\circ} \mathrm{C}\right)$ conditions. As a general rule, the performance of $\mathrm{AD}$ increases with temperature, as well as the bacteria growth rate, metabolic rate, and biogas production rate $[113,114]$. Reference [115] pointed out that thermophilic conditions produce double biogas than phychrophilic conditions. As reported by [116], thermophilic reaction suffers less from ammonia inhibition.

However, higher temperatures also represent some disadvantages. While endogenic reactions (acetogenesis) are enhanced with temperature, exergonic reactions, such as methanogenesis, reduce their performance. That is the statement for the events reported by [117], where in mesophilic conditions, $70 \%$ of the biogas is formed via acetoclastic methanogenesis, and the rest through hydrogenotrophic methanogenesis. In psychrophilic conditions all methane is produced by acetoclastic methanogens, hydrogen is oxidized and transformed, together with $\mathrm{CO}_{2}$ into acetate, and then into methane. However, in thermophilic conditions, homoacetogenic bacteria are capable of transforming acetate into hydrogen and carbon dioxide (In the opposite direction), and the methane inengenerated, almost entirely by hydrogenotrophic methanogenesis means.

\subsubsection{VFA and $\mathrm{pH}$}

VFA mainly comprise acetic, propionic, butyric, and valeric acid. They are by-products, formed in the acidogenic stages of the AD process, which can be ultimately transformed into $\mathrm{CH}_{4}$ and $\mathrm{CO}_{2}$. VFA play an important role in biogas production [118], as they are a key to constituting the final methanogenic stage, but an excess of it can cause a $\mathrm{pH}$ variation [119].

$\mathrm{pH}$ is another key parameter for the correct development of the anaerobic process. Anaerobic bacteria need different $\mathrm{pH}$ ranges for their growth: Fermentative bacteria around 4-8.5, and 6.5-7 for methanogens [120], so achieving a correct $\mathrm{pH}$ environment is essential for the process stability. VFA and $\mathrm{pH}$ are closely related. An excess of VFA can cause a drastic $\mathrm{pH}$ reduction. In addition, VFA can be significantly affected by $\mathrm{pH}$. When the $\mathrm{pH}$ is low, the main VFA present in the mixture are acetic and butyric acids. If the $\mathrm{pH}$ is high, around 8 , acetic and propionic acids are the dominant ones [121]. That is why controlling $\mathrm{pH}$ ratio can be a reliable method to achieve the stability in the process $[122,123]$. 


\subsubsection{Carbon, Nitrogen and C/N Ratio}

An optimal balance between nutrients is needed by anaerobic bacteria to enable their proper growth. A balance between $\mathrm{C}$ and $\mathrm{N}$ should be achieved, being commonly expressed by the $\mathrm{C} / \mathrm{N}$ ratio. Many researchers considered a $\mathrm{C} / \mathrm{N}$ ratio between 20 and 30 the optimal condition [124]. For example, [125] achieved the maximum methane potential at a $27 \mathrm{C} / \mathrm{N}$ ratio, and [126] did it also at $27 \mathrm{C} / \mathrm{N}$. Other researchers, like [24], obtained it at a $15.8 \mathrm{C} / \mathrm{N}$ ratio when co-digesting FW with cattle manure. However, the optimal $\mathrm{C} / \mathrm{N}$ ratio depends both on the substrate and the inoculum.

\subsubsection{Ammonia Content and Formation}

Ammonia is formed during the biodegradation of proteins or other nitrogen-rich substrates $[127,128]$. Ammonia and the $\mathrm{C} / \mathrm{N}$ ratio are directly related as high nitrogen contents produce ammonia formation, whilst $C$ content has a positive effect on avoiding ammonia inhibition $[125,129,130]$. Ammonia can act in two different ways, on one side enhancing the buffer capacity of AD neutralizing VFA [131,132], and, consequently, enhancing biogas production. On the other side, ammonia can act as an inhibitor for bacteria growth, especially acetoclastic methanogens [133-135], being responsible for methane production via acetate transformation. For example, an ammonia concentration between 400 and $5700 \mathrm{mg} / \mathrm{L}$ produces a $56 \%$ loss of methanogens activity, while acidogens were not affected $[133,136]$. Ammonia content increases with temperature and $\mathrm{pH}$, so it is related with other basic parameters [137]. Ammonia as an inhibitor has been widely studied in order to set or establish the threshold between its positive effect (exploiting its buffer capacity) and its negative effect (as inhibitor). As an example, in semicontinuous AD of FW, the inhibition effects were observed when the ammonium concentration in the AD reactor exceeded $2 \mathrm{~g} / \mathrm{L}$ [138]. Below this threshold, ammonium acted as a buffer neutralizing the acidification effect from VFA accumulation. Over the limit, ammonia strongly inhibited methanogenesis shifting methane formation from acetate by acetoclastic methanogens to a syntrophic acetate oxidation, leaving hydrogenotrophic methanogenesis as the only methane formation way. However, it did not affect the hydrolysis and acidification stages, causing an acetate and propionate accumulation with its consequent $\mathrm{pH}$ decrease.

High concentrations of ammonia can lead to lower biogas production, and also to ammonia emission from the effluent, making the digestate less suitable as fertilizer [139-142]. Many techniques for ammonia removal had been studied and approached, combining physical, chemical, and biological techniques [141,143-147].

\subsubsection{Long-Chain Fatty Acids}

Long-chain fatty acids (LCFA) are the main by-products of the lipid degradation process [148,149]. LCFA are, subsequently, converted into hydrogen and acetate during acidogenesis stage through a $\beta$-oxidation reaction, and finally, into methane. This is the reason why acetogenesis could be considered a rate-limiting stage of the AD process [34,150], along with hydrolysis. Inhibition from LCFA can be caused, according to various research studies, by high concentrations of LCFA that result in a $\mathrm{pH}$ decrease and the subsequent growth reduction of the methanogenic archaea [151-153], or because of the LCFA adsorption onto the microbial cell wall and membrane. This affects the metabolic process of transportation [151,154,155]. Moreover, inhibition that is caused by LCFA has a synergic effect, meaning that the inhibition degree due to a mixture of LCFA's is higher than the effect that is caused by each individual acid [156].

When considering that theoretical methane potential of lipids is higher than carbohydrates, as it will be discussed later, serious problems in biogas plants are caused by the inhibition of LCFA. Strategies for recovering this inhibition have been studied by many researchers, for example, by increasing the biomass/LCFA ratio [155] or using discontinuous feeding [157]. 


\subsubsection{Metal and Heavy Metals Traces}

Together with nutrients $(\mathrm{C}, \mathrm{H}, \mathrm{O}, \mathrm{N})$, light metals $(\mathrm{Na}, \mathrm{K}, \mathrm{Meg}, \mathrm{Ca})$, and heavy metals $(\mathrm{Cr}, \mathrm{Co}, \mathrm{Zn}, \mathrm{Cu})$ are necessary for anaerobic bacteria to develop enzyme synthesis and activity maintenance [158,159], although an excess of metal concentration can lead to AD inhibition.

In FW, concentration of heavy metals is almost insufficient $[46,160]$ while light metals such as $\mathrm{Na}$, $\mathrm{K}$, and Ca are, generally, found at high concentration levels $[47,84,161]$, as can be observed in Table 1 , which summarizes metal concentrations in FW reported by several researchers.

Heavy metals are supposed to cause inhibition due to a disruption of the enzyme function and structure of microorganisms [133]. Regarding light metals, $\mathrm{Na}$, for example, creates an optimal environment for methanogens in 350-400 $\mathrm{mg} / \mathrm{L}$ [133] and concentration, respectively. K was capable of enhancing methanogenesis in mesophilic and thermophilic conditions. Ca, on its own, has a controversial effect: Some researchers discovered that no inhibition was found when the Ca concentration was really high, specifically up to $7000 \mathrm{mg} / \mathrm{L}$ [162], others found out that the optimum Ca concentration range is $150-300 \mathrm{mg} / \mathrm{L}$ [163], or with a toxicity threshold even lower, up to 200 $\mathrm{mg} / \mathrm{L}$ [164].

\subsection{Anaerobic Mono-Digestion of FW}

$\mathrm{AD}$ is a synergistic process between microbes' population. $\mathrm{AD}$ mono-digestion means that the substrate, FW in this case, is treated solely with the consortium of anaerobic microbes, under anaerobic (non-air and non-oxygen) conditions. AD is more suitable for food waste treatment than other conventional treatments, because of its composition, as it recovers energy, and, in addition, digestate can be applied for agricultural uses.

Biogas production and methane production from FW AD can be estimated through its composition, previously reviewed. Biogas yield is affected mainly by LPCH content and its balance. Some theoretical results in terms of biogas yield and biogas composition from degradation pf proteins, lipids, and carbohydrates, can be determined through methane production equations, especially the Buswell-Muller formula [165] and the Boyle formula [166] when elemental and chemical composition of compounds are known:

$$
\begin{aligned}
\mathrm{C}_{\mathrm{a}} \mathrm{H}_{\mathrm{b}} \mathrm{O}_{\mathrm{c}} & +\left(\mathrm{a}-\frac{\mathrm{b}}{4}-\frac{\mathrm{c}}{2}\right) \mathrm{H}_{2} \mathrm{O} \rightarrow\left(\frac{\mathrm{a}}{2}+\frac{\mathrm{b}}{8}-\frac{\mathrm{c}}{4}\right) \mathrm{CH}_{4}+\left(\frac{\mathrm{a}}{2}-\frac{\mathrm{b}}{8}+\frac{\mathrm{c}}{4}\right) \mathrm{CO}_{2} \\
& \rightarrow\left(\frac{\mathrm{a}}{2}+\frac{\mathrm{b}}{8}-\frac{\mathrm{c}}{4}-\frac{3 \mathrm{~d}}{8}-\frac{\mathrm{e}}{4}\right) \mathrm{CH}_{4}+\left(\frac{\mathrm{a}}{2}-\frac{\mathrm{b}}{8}+\frac{\mathrm{c}}{4}+\frac{3 \mathrm{~d}}{8}+\frac{\mathrm{e}}{4}\right) \mathrm{CO}_{2}+\mathrm{dNH}_{3}+\mathrm{eH}_{2} \mathrm{~S}
\end{aligned}
$$

According to this procedure, to obtain the theoretical biogas yield and composition, it is interesting to know the chemical composition of $\mathrm{LPCH}$, as shown in Table 2. This provides the maximum biogas yield that can be obtained, assuming that the entire substrate is transformed into biogas, although part of the substrate is converted into biomass (3-10\%) [167] and it is thus not available for biogas formation.

Table 2. Chemical composition of lipids, proteins, carbohydrates, theoretical biogas yield and biogas

\begin{tabular}{|c|c|c|c|c|c|c|c|c|c|}
\hline $\begin{array}{c}\text { C } \\
\text { [\%weight] }\end{array}$ & $\underset{[\% \text { weight] }}{\mathbf{H}}$ & $\underset{[\% \text { weight }]}{\mathrm{N}}$ & $\begin{array}{c}\text { O } \\
{[\% \text { weight }]}\end{array}$ & $\underset{[\% \text { weight }]}{\mathrm{S}}$ & Ref. & $\begin{array}{l}\text { Theoretical } \\
\text { Biogas Yield } \\
\text { [Nl/kg-TS] }\end{array}$ & \multicolumn{2}{|c|}{$\begin{array}{c}\text { Theoretical Biogas } \\
\text { Composition }\left[\% \mathrm{CH}_{4}\right. \\
\text { vol.] }\left[\% \mathrm{CO}_{2} \text { vol. }\right]\end{array}$} & Ref. \\
\hline 76 & 12 & - & 12 & - & & 1390 & 72 & 28 & \\
\hline 46 & 5 & 18.5 & 30 & 0.5 & [37] & 800 & 60 & 40 & [149] \\
\hline 40 & 7 & - & 53 & - & & 750 & 50 & 50 & \\
\hline
\end{tabular}
composition from lipids, proteins, and carbohydrates (LPCH) calculated using Buswell-Mueller [165] and Boyle [166] formulas. 
Carbohydrates $\left(\left(\mathrm{CH}_{2} \mathrm{O}\right)_{n}\right)$ exhibit the fastest conversion rate but the lowest biogas yield $[133,168,169]$, around $750 \mathrm{Nl}$ per kilogram of total solids, with a biogas composition of $50 \% \mathrm{CH}_{4}$ and $50 \% \mathrm{CO}_{2}$. Carbohydrate-rich substrates, in FW terms, such as fruit and vegetable waste or sugar industry wastes, are enriched with simple sugars and disaccharides [75]. Anaerobic degradation of simple sugar may result in VFA formation and accumulation, leading to a $\mathrm{pH}$ decrease and methanogenesis inhibition [75]. Mixing them with low organic content substrates $[124,170]$ might balance operational conditions and biogas production [171].

On their behalf, proteins $\left(\mathrm{C}_{\mathrm{a}} \mathrm{H}_{\mathrm{b}} \mathrm{O}_{\mathrm{c}} \mathrm{N}_{\mathrm{d}} \mathrm{S}_{\mathrm{e}}\right)$ represent a fast conversion to biogas and a biogas yield $[169,172]$ slightly above carbohydrates $(800 \mathrm{Nl}$ per kilogram of total solids) with a higher methane composition, $60 \% \mathrm{CH}_{4}$ against $40 \% \mathrm{CO}_{2}$. As protein structures are different from each other, biogas content may vary significantly. $\mathrm{CH}_{4}$ content that is given in Table 2 is typical for amino acids. Since many proteins can be present in a less oxidised form, methane content can increase up to $70 \%$. Not only is methane released, but also ammonia and hydrogen sulphide can be obtained, as they are the only compounds that present $\mathrm{N}$ and $\mathrm{S}$ in their composition (a common point between amino acids is that those have an amine group $\left(-\mathrm{NH}_{2}\right)$ [75]). If an excess of ammonia is released it can deliver in a process inhibition [173]. FW protein rich materials, such as meat residue, slaughterhouse waste, or manure require a suitable adjustment of $\mathrm{C} / \mathrm{N}$ ratio and an optimum key parameter control to avoid process inhibition and system failure due to problems described.

Finally, lipids $\left(\mathrm{CH}_{3}\left(\mathrm{CH}_{2}\right)_{n} \mathrm{COOH}\right)$ show the highest biogas yield, as they have a higher carbon composition (C:16-C18 typically), providing $1390 \mathrm{Nl}$ of biogas per kilogram of total solids of which around $72 \%$ is $\mathrm{CH}_{4}$. However fats require longer retention times due to their slow biodegradability [83], and, in addition, a lipid excess can lead in a process inhibition due to an excessive VFA and LCFA release and accumulation [34] due to toxic products formation [157]. Lipid-rich products, regarded in FW terms as slaughterhouse residues and wastewaters, dairy products, edible oil products, and mill loses [75], present a huge biogas yield, but leading in blocking AD process, adsorption to biomass causing mass transfer problems and foam formation [172], and inhibiting hydrolysis and microbial process due to VFA and LCFA releasing [169,174-176]. Mixing lipid-rich elements with carbohydrate-rich substrates produces a nutrient balance for microorganisms' enrichment, reducing the accumulation of inhibitors.

To manage full AD implementation, as well as to predict methane production, experimental results are necessary, and BMP (Biochemical Methane Potential) is required [177]. BMP is an experimental measure of the substrate biodegradation potential and methane gas generation [178] that provides the maximum methane output that is achieved in laboratory incubation tests under optimum anaerobic conditions [179]. The theoretical BMP (TBMP) can be estimated as the weighted average of individual TBMP for organic components [44,180,181], as explained previously with Buswell-Muller and Boyle's formulas.

Food waste biodegradability has been thoroughly researched, as can be observed in Table 3 . Most of the studies reported that mono-digestion of FW was not sufficient and limited due to lack of nutrients (nitrogen and phosphorus) and metal traces, and the inhibition that is created by the accumulation of ammonia and VFA, resulting in the high biodegradability and protein and lipid content [182-184].

This problem can be solved with digester modifications, such as nutrient recirculation, pre-treatments, temperature increases [48,185], or with an even better solution: Co-digestion. 
Table 3. Food waste (FW) biodegradability through anaerobic mono-digestion and co-digestion experiences.

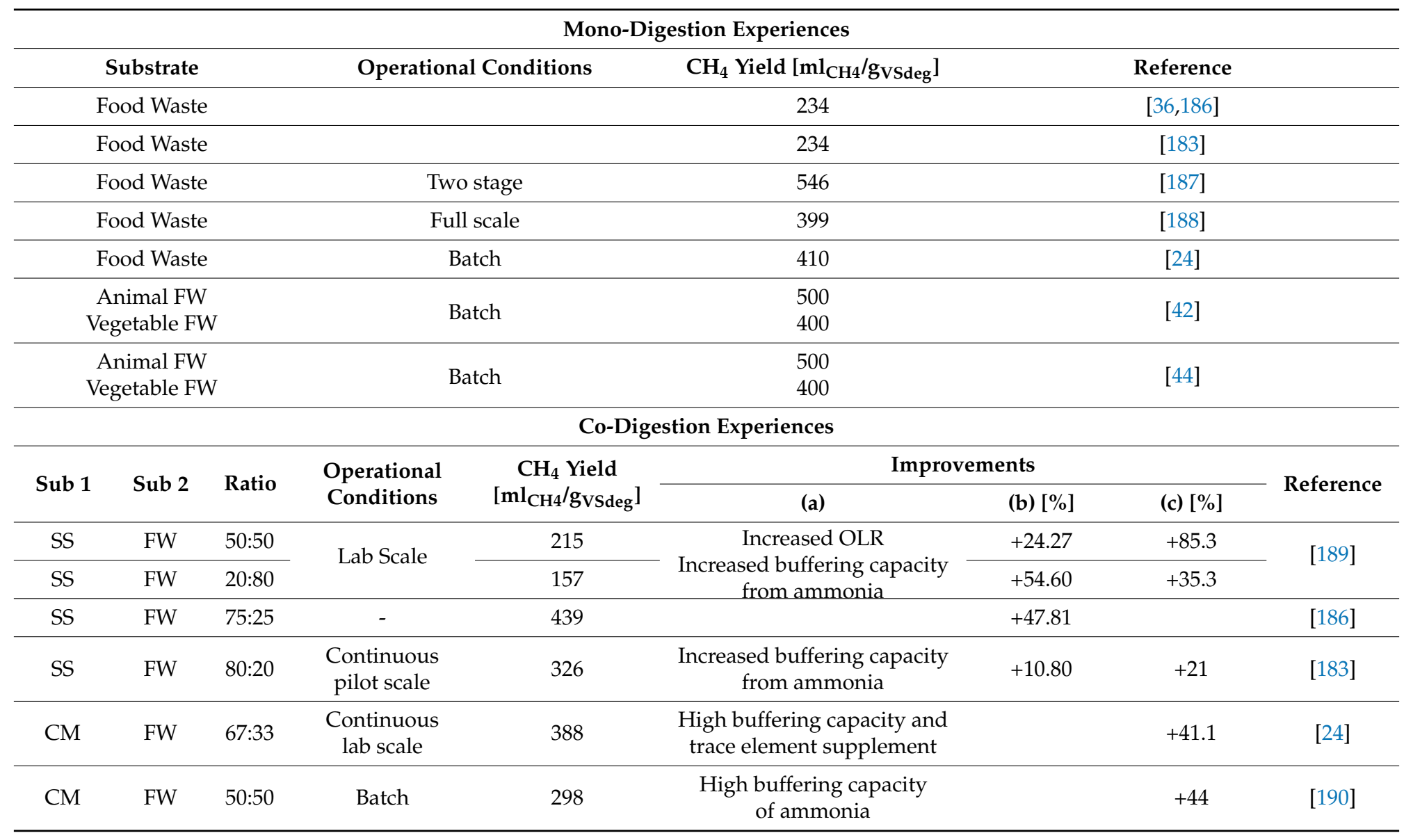


Table 3. Cont.

\begin{tabular}{|c|c|c|c|c|c|c|c|}
\hline \multicolumn{8}{|c|}{ Co-Digestion Experiences } \\
\hline \multirow{2}{*}{ Sub 1} & \multirow{2}{*}{ Sub 2} & \multirow{2}{*}{ Ratio } & \multirow{2}{*}{$\begin{array}{l}\text { Operational } \\
\text { Conditions }\end{array}$} & \multirow{2}{*}{$\begin{array}{c}\mathrm{CH}_{4} \text { Yield } \\
{\left[\mathrm{ml}_{\mathrm{CH} 4} / \mathrm{g}_{\mathrm{VSdeg}}\right]}\end{array}$} & \multicolumn{2}{|c|}{ Improvements } & \multirow{2}{*}{ Reference } \\
\hline & & & & & (a) & (b) $[\%]$ & \\
\hline WAS & FW & 90:10 & - & 186 & $\begin{array}{l}\text { Nutrient balance. } \\
\text { Increased buffering capacity } \\
\text { from ammonia }\end{array}$ & $\begin{array}{l}\mathrm{CH}_{4} \text { yield increases while } \\
\text { addition of } \mathrm{FW} \text { increases. }\end{array}$ & [192] \\
\hline $\mathrm{frW}$ & $\mathrm{CM}$ & $20: 80$ & \multirow{4}{*}{ Batch } & 380 & \multirow{4}{*}{$\begin{array}{c}\text { Nutrient and } \mathrm{C} / \mathrm{N} \text { ratio } \\
\text { balance. } \\
\text { High buffer capacity }\end{array}$} & \multirow{4}{*}{$\begin{array}{l}\mathrm{CH}_{4} \text { yield increases while } \\
\text { addition of } \mathrm{FW} \text { increases. }\end{array}$} & \multirow{4}{*}{ [193] } \\
\hline $\mathrm{frW}$ & $\mathrm{CM}$ & $30: 70$ & & 340 & & & \\
\hline $\mathrm{frW}$ & $\mathrm{CM}$ & $40: 60$ & & 380 & & & \\
\hline $\mathrm{frW}$ & $\mathrm{CM}$ & $50: 50$ & & 450 & & & \\
\hline
\end{tabular}

(b) Improvement is defined as the increase in $\mathrm{CH}_{4}$ yield compared to $\left(\mathrm{CH}_{4}\right.$ yield of main substrate $+\mathrm{CH}_{4}$ yield of co-substrate $) \rightarrow$ Synergistic effect

(c) Improvement is defined as the increase in $\mathrm{CH}_{4}$ yield compared to $\mathrm{CH}_{4}$ yield of the main substrate itself $\rightarrow$ Global effect.

Abbreviations:

SS (Sewage Sludge) CM (Cattle Manure) ShW (Slaughterhouse Waste) WAS (Waste Activated Sludge) frW (Fruit Waste) PWw (Piggery

Waste Water) 


\section{Anaerobic Co-Digestion of Food Waste}

Anaerobic co-digestion can be defined as the simultaneous treatment of various substrates, at the same time, in the same anaerobic digester with the same inoculum.

Digesting FW solely is a suitable solution for FW generation and management. However, not all biogas yield is released, and, in addition, inhibition may occur. The main reason might be a nutrient imbalance between organic compounds $(\mathrm{LPCH})$ in the anaerobic digester, a lack of trace elements ( $\mathrm{Fe}, \mathrm{Zn} \ldots$ ) combined with a macronutrient excess $(\mathrm{Na}, \mathrm{K}, \mathrm{Ca} \ldots$ ), and a non-optimum $\mathrm{C} / \mathrm{N}$ ratio $[24,46,47,194]$. Problems and inhibitions caused by each organic element were formerly reviewed in previous sections.

Anaerobic co-digestion (CoAD) means mixing substrates, for example, FW and sewage sludge [36], FW and manure [24], or even straw [82] and slurry [195], to balance nutrients in the digester providing a more stable environment for anaerobic bacteria $[190,196,197]$.

The main advantage of CoAD, is the synergy that is created between substrates in terms of biogas yield, biogas composition and methane enrichment. This means that biogas created whilst digesting two substrates simultaneously, is higher than the sum of each mono-digestion $(A B>A+B)$. Actually, CoAD can enhance biogas production from $35 \%$ to $400 \%$ over the mono-digestion of each substrate [198,199]. Other important advantages are achieved with CoAD [199-206], such as, (a) improvement of process stabilization, (b) dilution of inhibitory substances, (c) higher buffer capacity due to higher ammonia from organic wastes, (d) nutrient balance, (e) optimum C/N ratio achievement, (f) trace element supplement, (g) increasing the total amount of OM loaded, (h) synergy between substrates in biogas yield, (i) improving moisture content, (j) methane enrichment and its subsequent greenhouse emissions reduction, and ( $\mathrm{k}$ ) economic feasibility.

FW can be used in CoAD as co-substrate or main substrate, according to its compositions, the other substrate should benefit the balance. When FW is used as a co-substrate, the main substrate is, typically, sewage sludge (SS) and animal manure (AM). These two (FW and AM) are characterized by a low $\mathrm{C} / \mathrm{N}$ ratio resulting in a high accumulation of ammonia in the digester. Adding FW increases the $\mathrm{C} / \mathrm{N}$ ratio and it improves digestion as a consequence of ammonia reduction [183,204,207]. FW also dilutes inhibitors and toxicity caused by heavy metals and pathogens, clearly existing in SS and AM. However not only is the main substrate benefited by co-digestion of FW, but also SS and AM act with a high buffer capacity, which are able to withdraw $\mathrm{pH}$-low problems caused in FW mono-digestion by VFA and LCFA accumulation during the degradation of OM, especially the lipidic content [208,209].

The use of FW as a main substrate requires employing a co-substrate capable of reducing inhibition problems of $\mathrm{AD}$ of $\mathrm{FW}$ and enhancing biogas yield. As stated in previous sections, methanogenic activity while digesting FW is often inhibited due to the accumulation of VFA and LCFA from lipids and carbohydrates biodegradation, to the lack of nutrients, such as $\mathrm{N}$ or $\mathrm{P}$, and trace metals. FW has been traditionally digested along with straw and other lignocellulosic substrates, solid waste leachate, wastewater (industrial and agroindustrial, such as piggery wastewater), slaughterhouse waste, manure, and sewage sludge [4]. These co-substrates create a synergy in biogas yield due to several reasons: Lignocellulosic substrates (i.e., straw) increase the $\mathrm{C} / \mathrm{N}$ ratio and biogas production; moreover, it decreases hydrolysis rate because of its low degradability, and consequently reduces VFA accumulation and inhibition, providing stability [210,211]. Wastewater and OFMSW leachate dilute FW lipidic content and feed it with nutrients and metal elements that are not present, or in small amounts, in FW. Nevertheless, the main achievement of this co-digestion is the improvement of enzymatic reactions, and, consequently, hydrolysis improvement [66,191,212]. However, organic loading in co-digestion has to be regarded carefully, especially when co-digesting FW with manure or leachate due to its high biodegradability, which can lead to a process saturation and failure $[110,213]$. Organic loading rate and mixture ratio must be carefully regarded when digesting FW with high biodegradable wastes, for example, slaughterhouse waste, which also presents high lipid content. This can deliver, not only LCFA and VFA accumulation and inhibition, but also foaming and fat accumulation in the reactor, because of its high lipid and carbohydrate content. 
Co-digestion of FW with sewage sludge (SS) from wastewater treatment plants is an excellent and suitable solution, not only for its benefits in terms of synergy in biogas production, methane yield, and process stability, but also because of its advantages in economic and environmental aspects, which will be discussed further on and is the reason why co-digestion of FW and SS is reviewed in a separated section. Table 3 summarizes co-digestion experiences, providing data of biogas enhancement and the improved mechanism of co-digestion.

\section{Anaerobic Co-Digestion of Food Waste and Sewage Sludge}

Improved biogas and methane yield in CoAD of SS and FW has been widely studied and comes from various aspects: (a) mixture and $\mathrm{C} / \mathrm{N}$ ratio, (b) nutrient balance and dilution of inhibitors and toxic elements, and (c) changes in hydrolysis rate.

Sewage sludge is characterised by a low C/N ratio ranging between 6 and 9 [189,195]. On its own, FW has a higher $\mathrm{C} / \mathrm{N}$ ratio that can improve the $\mathrm{C} / \mathrm{N}$ ratio of substrates blend if a correct mixture ratio is utilized, providing more carbon, essential for improving digestion process and kinetics [214-216]. Optimum C/N ratio has traditionally been settled between 20 and 30 [186,192,217-219]. A higher C/N ratio is usually a cause of process disability due to a nutrient $(\mathrm{N})$ deficiency, whilst low $\mathrm{C} / \mathrm{N}$ ratios represent low carbon availability in combination with high ammonia formation and its subsequent toxicity for the AD process in high concentrations [220].

Nutrient balance provided by FW and SS sludge co-digestion has its fundamentals in achieving the optimum $\mathrm{C} / \mathrm{N}$ ratio, and creating an equilibrium between $\mathrm{LPCH}$ content. Each one has its own benefit in biogas yield terms, but a balance must exist to achieve the optimum environment and intermediate product creation for the process. Adding FW can also dilute toxic compounds such as heavy or light metal and organic compounds, mainly present in SS [133,221]. This may affect the digestion progress [222,223], but if proper dilution is achieved, then digestion performance can improve $[224,225]$ as well as methane yield [226].

Hydrolysis, considered to be the rate and stage limiting step of AD process [216], is also improved when adding FW to SS digestion. In general terms, SS has a rich content in proteins [227,228], connected with the lowest hydrolytic and biogas yield of LPCH. Adding FW, in the form of simple biodegradable matter accelerates hydrolysis because of the faster growth of anaerobic archaea $[205,229,230]$. This acceleration in microbial growth not only increases hydrolysis yield and kinetics, it does the proper within the acidification and methanogenesis steps, resulting in a higher potential $[94,186,228,231]$.

However, some constraints have to be regarded in order to improve the feasibility of FW CoAD with SS. This process is mainly limited due to the high variability of FW depending on its procedure, nature, and characteristics. Anaerobic microorganisms are acclimatised in a specific environment, and sudden changes in substrate and reactions might break the equilibrium [105]. Addition of FW, especially carbohydrate-rich ones, results primary in an increase of VFA concentration [218] that should be transformed into methane. However, a VFA excess or accumulation causes acidity in the digester and slows down the process. A high-lipid income in the digester may result in LCFA accumulation with the same acidity consequences. On its own, protein-rich substrates are the causes of ammonia accumulation. Overloading digesters with FW has to be avoided in order to reduce changes in microorganism activity and its subsequent reduction of biogas and methane yields. 


\section{Pre-Treatments for Anaerobic Digestion of Food Waste}

Pre-treatments are usually employed to increase substrate solubility and accelerate biodegradation rate when digesting particulate organic matter [110,232]. Hydrolysis, including the "disintegration stage", is considered the stage and rate-limiting step of $\mathrm{AD}$, as its target is to prepare OM for a feasible digestion. If the accessibility to substrate is increased, the conversion yield will be significantly increased as well, and the process develops with no interruptions [233]. Pre-treatments are, therefore, any previous action to substrate in order to weaken its cell wall and structure, facilitating hydrolysis by terms of allowing for enzymes and methanogens to consume organic compounds inside the cell $[95,234]$.

Pre-treatments can be classified into various categories, such as (a) mechanical and physical, (b) chemical, (c) thermal, and (d) biological pre-treatments. All of them aim for the same target, improving hydrolysis and facilitate solubilization, through different mechanisms. The basis of these pre-treatments is described below, provided together with experiences and results in Table 4. 
Table 4. Pre-treatments for anaerobic digestion and co-digestion of food waste: Basis and influence.

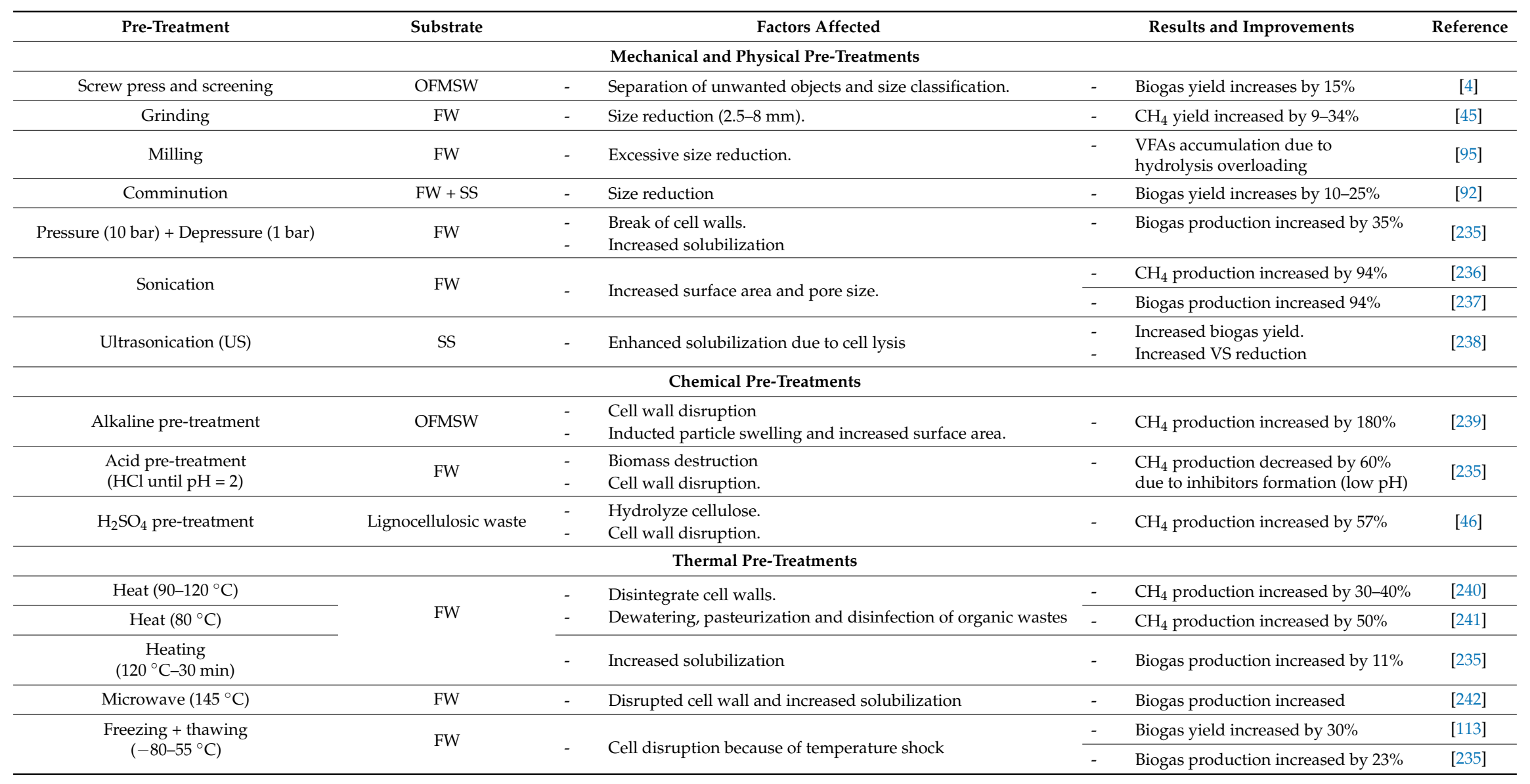


Table 4. Cont.

\begin{tabular}{|c|c|c|c|c|}
\hline Pre-Treatment & Substrate & Factors Affected & Results and Improvements & Reference \\
\hline \multicolumn{5}{|c|}{ Biological Pre-Treatments } \\
\hline Biological solubilization & FW + Waste Water & Increasing solubilization & $\begin{array}{l}\text { - } \quad \begin{array}{l}\text { Reduction of organic concentration in } \\
\text { the digestate }\end{array} \\
\end{array}$ & [243] \\
\hline Composting & OFMSW & Increased hydrolysis potential by pre-degradation & $\mathrm{CH}_{4}$ production increased by $73.3 \%$ & [244] \\
\hline Microaireation & FW & Inducted particle swelling and increased surface area. & Biogas yield increased by $23 \%$ & [245] \\
\hline Two stages & OFMSW & Low and high $\mathrm{pH}$ stages respectively separated. & $\mathrm{CH}_{4}$ production increased by $21 \%$ & [246] \\
\hline \multicolumn{5}{|c|}{ Combination of Pre-Treatments } \\
\hline Bacterial hydrolysis and alkaline addition & $\mathrm{FW}+\mathrm{SS}$ & $\begin{array}{ll}- & \text { Increased hydrolysis potential. } \\
- & \text { Cell wall disruption and inducted particle swelling }\end{array}$ & Biogas yield increased by $140 \%$ & [247] \\
\hline $\begin{array}{l}\text { Thermo-acid } \\
\left(\mathrm{HCl}+120^{\circ} \mathrm{C}\right)\end{array}$ & FW & Increased solubilization & Biogas production increased by $18 \%$ & [235] \\
\hline $\begin{array}{l}\text { Thermo-acid } \\
\left(\mathrm{HCl} \text { at } 100^{\circ} \mathrm{C}\right)\end{array}$ & OFMSW & Increased solubilization & Biogas production increased by $120 \%$ & [248] \\
\hline $\begin{array}{l}\text { Bio-Physico-Chemical } \\
\text { (Bacillusat + US + Acid) }\end{array}$ & Oil + Waste Water & Enhanced oil degradation & Biogas production increased by $280 \%$ & [249] \\
\hline
\end{tabular}




\subsection{Mechanical and Physical Pre-Treatment}

Mechanical and physical pre-treatments are based on separation of large and unwanted materials from the $\mathrm{OM}$, and reducing its particle size, as increased contact surface allows for a better contact and interaction between substrate and microorganisms [34,45]. If particle size is sufficiently reduced, methane yield can be improved up to $40 \%$. The most common procedures to reduce particle size are milling, screw press, disc screen, or shredder with magnet methods. As an example, researchers found an improvement a biogas yield improvement of 9-34\% when grinding FW previously to its anaerobic treatment [45], an increase in biogas yield of $20 \%$ if substrate was comminute [92] or a $94 \%$ increment in both, biogas and methane yield, if FW is previously grinded and sonicated [236,237]. However, an excessive reduction of particle size can lead to a hydrolysis overloading and the subsequent VFA accumulation. This has been reported when treating milled FW [95], causing a collapse in the methanogenic reaction.

Another mechanical pre-treatment gaining ground is sonication, consisting in disrupting cell structure and floc matrix of particulate matter by means of ultrasonic waves [250]. In this case, biogas enhancement is due to an improved solubilization [237] that can increase the methane yield up to $90 \%$ [236]. However, this pre-treatment is not yet feasible to use in-situ in big-scale plants.

Other physical type of pre-treatment aims to increase surface area and pore size by disrupting biomass structure and increasing solubilization $[235,251]$. This is the case of pressure-depressure pre-treatments that can increase biogas yield up to 35\% [235] when substrate is first under pressure (10 bar), and finally depressurised, achieving the breakup of cell walls. Irradiation can also be considered a successful pre-treatment disrupting biomass cell structure and decreasing crystallinity of cellulosic components [252,253].

\subsection{Chemical Pre-Treatments}

With these pre-treatments, cell disruption and biomass accessibility is searched for by addition of strong acids and alkalis in order to previously destroy biomass [254]. The main objective is to hydrolyse cellulosic materials, especially food waste containing vegetable and lignocellulosic substrates $[4,110]$. Experiences by using alkali pre-treatment show that biogas yield can be increased up to $170 \%$ [239], because particle swelling was inducted, thus increasing surface area. Also, lignin surface is disrupted and the structural linkages between lignin and carbohydrates $(\mathrm{CH})$ are broken, so $\mathrm{CH}$ are more accessible and subsequently converted into biogas [251]. On its own, acid pre-treatments are useful for treating lignocellulosic substrates [255], as it is useful for disrupting the strong cells. However, for FW it is not so suitable, leading to a biogas yield decrease of $66 \%$ [235] due to the formation of inhibitor at low $\mathrm{pH}$ such as carboxylic acids and phenolic compounds [256].

\subsection{Thermal Pre-Treatments}

Exposing substrate to temperature changes over a period of time, is known as thermal pre-treatment [257]. These pre-treatments could be included in a physical category, however, due to its feasibility and suitability, are usually considered in a separated category. The thermal pre-treatment purpose is to disintegrate cell walls and membranes to increase solubilization of OM [258]. Subjecting FW and substrates to temperatures between a range of $50-160{ }^{\circ} \mathrm{C}$ results in an increase of biogas production around 30-35\% [191,240,259] or even 50\% [241]. For temperatures that are out of the range, $\mathrm{AD}$ performance and biogas yield are decreased compared with the biogas yield obtained with non-treated substrate, as inhibitory and refractory compounds appear in the digester. That is exactly what happens when thermal pre-treating slaughterhouse waste [260], lipids were turned into VFA acid, and the $\mathrm{AD}$ process resulted in foaming inside the reactor, leading to an overload of the system.

Feasibility of thermal pre-treatments came also from other benefits of applying them, for example, pathogen removal [261] or dewatering performance [241], which reduced the viscosity of digestate, making it more feasible for later transportation. 
Freezing and thawing is also considered as a thermal pre-treatment, but, in this case, submitting substrate to sub-zero temperatures (freezing) and afterwards recovering its temperature (thawing). In this case, biogas yield increased around 30\% [113], due to cell disruption that is caused by the temperature change. This pre-treatment has not been widely used, mainly because of its high operational cost, but it is extremely adequate and feasible for FW as freezers are always present in agri-food industry facilities.

\subsection{Biological Pre-Treatments}

Biological pre-treatments often consist of aerobic or anaerobic treatment before the main $\mathrm{AD}$ process, in order to increase the enzymatic population or increase the process development [4].

Aerobic pre-treatment, for example, [244] subsequently increases hydrolysis potential, resulting in higher biogas creation up to $70 \%$. However, an excessive aireation can lead to a biogas production decrease due to VFA formation and accumulation [245].

Anaerobic pre-treatments, on their own, consist of separating various phases in two different reactors (hydrolysis-acidogenesis from acetogenesis-methanogenesis) [246], so optimal conditions are achieved in both processes and key parameters, especially $\mathrm{pH}$, can be controlled and optimized to lead to higher biogas formation. In one reactor, $\mathrm{pH}$ is lowered to acidity conditions (from 4 to 6), and hydrolysis-acetogenesis is carried out, even breaking down inhibiting chemicals for the second stage microorganisms [260]. In the other reactor, the $\mathrm{pH}$ value is maintained from 6.5 to 8 for a proper growth of methanogenic population [262]. Also, less VFA are found in this reactor as they are easily converted into methane, avoiding VFA accumulation. This stage separation achieves biogas increases up to $20 \%$ [262], as many researchers found when comparing single stage and two-stage anaerobic digestion, revealing bioaugmentation and its effects [263] However, two-stage digestion is not so commonly used in full-scale plants, as single stage reactors are simpler to operate [199].

\section{Environmental Impacts of Anaerobic Digestion of FW with Sewage Sludge}

As waste management plays an important role in environmental engineering, studying its environmental impact appears as an essential part of its feasibility and applicability [264]. Through the years, many tools have been used. However, the most suitable and powerful tool for determining environmental, and even economic and social impact of waste management is Life Cycle Assessment (LCA) [265]. LCA enables comparing and quantifying the impacts of different waste solutions, acting as a support tool for decision making in waste management. If LCA is applied to anaerobic digestion of food waste (and sludges for Waste Water Treatment Plants), the following conclusions can be reached:

Mostly, all of the environmental impacts of AD are due to climate change. A large part are caused by methane leaks and other accidental emissions during the $\mathrm{AD}$ process. As methane is the major component of biogas and it is considered a greenhouse effect gas, these emissions should be taken into account. In order to reduce leaks and their impact, flaring systems and emergency torches are usually incorporated in biogas plants $[33,266,267]$. Other impacts are usually related to different gas leaks that cause acidification and eutrophication [268,269]. Mainly, because high ammonia or hydrogen sulphide biogas contents, which are important parameters used as control factors in biogas production with food waste as substrate, and digestate uses. Acidifications come from biogas combustion, resulting in nitrogen oxide and sulphur dioxide emissions $[13,270]$. Both are considered secondary particulate precursors, resulting in particulate matter formation. On the other hand, eutrophication can be a result of digestate management [271,272], as it contains a high level of $\mathrm{N}$, and it is usually considered as fertilizer.

However, when comparing AD with other waste management solutions, it seems to be, if not the best, one of the most preferable environmental solutions. Studies have been carried out [4] when comparing different scenarios and their impacts, showing CoAD treatment as the most viable solution, in spite of its undesirable impacts, as it generates the highest amount of renewable energy in form of biogas turning this disposal method into an energy recovery system. Biogas can be used 
in different forms: for electricity generation, heat production $[14,273,274]$, and even for vehicle use through biogas upgrading [12,275]. Also, biogas is used in cogeneration, producing heat and electricity simultaneously. Biogas can supply energy in form of electricity to the principle industries, as well as to those close or nearby, excess is often delivered to the public grid. Heat can be used internally to maintain the anaerobic reactor temperature and to provide heat and steam to industries. It can also be connected to district heating systems. Moreover it will be upgraded and injected to the gas grid for household use, or used as fuel, meeting traditional fuel standards through purification processes. Environmental emissions from biogas utilization should also be considered, although methane is the cleaner hydrocarbon due to its lower carbon content.

\section{Conclusions and Perspectives}

$\mathrm{AD}$ and CoAD appear as reliable and feasible solutions and technologies for recycling and recovering both sewage sludge and food waste. In economic, social, and environmental terms, it seems to be the best waste management option, because it is a renewable energy source with low emissions. Although a more thorough knowledge of the process is needed in order to ensure the proper development and stability of the microbial degradation.

Addition of FW to SS anaerobic digesters enriches the nutrient content, dilutes inhibitors, increases the alkalinity, and reduces ammonia formation, so the stability of the process is enhanced.

However, due to the origin and composition diversity of FW, which gives specific properties to them, a well-known characterisation is needed to combine them in the correct proportion to enhance biogas production and stability of the process. Protein rich compounds show a fast conversion to biogas, but ammonia and sulphides can be released. On their behalf, carbohydrates show the fastest conversion rate, but methane yield is not so elevated. Lipids represent the highest biogas yield, but it can lead to process inhibition due to VFA and LCFA accumulation and foam formation. However, a buffer system between ammonia and VFA can be formed, as occurs when co-digesting FW and SS. In essence, $\mathrm{AD}$ challenges from the technical point of view, are related with the process stability and development, such as VFA accumulation, foaming, low buffer capacity, and fast acidification, with its consequent inhibition of methanogens. In this context, multi-stage systems arise as a feasible solution.

Pre-treating substrates constitutes a way of improving and increasing anaerobic degradation. In FW terms, pre-treatments mainly consist of size reduction for a better cell wall disruption, and this enables a better hydrolysis stage, as well as enhancing biogas rate and yield. However, an excessive pre-treatment can cause VFA accumulation and its subsequent inhibition due to hydrolysis overloading.

In light of this, a correct separation and characterisation of FW is needed, at both household and industrial levels, to help to predict biogas formation and the development of the anaerobic process, ensuring a correct nutrient balance, reducing lipid content, and achieving an appropriate $\mathrm{C} / \mathrm{N}$ ratio. This objective can be reached with better planning and separation methods, by local authorities, who must keep in mind the importance of social awareness.

Economic cooperation for $\mathrm{AD}$ is also needed to improve and establish a circular economy. A distributed ion system for biogas production with many smaller plants, instead of few high capacity plants, could help to reduce transportation costs. This would lead to a continuous process making the digester less sensitive to input changes. Buffer capacity could be increased, along with the balance and stability between biogas/methane rates. Under these terms, wastewater treatment plants seem a perfect solution, because of their multiplicity and continuous operation. In addition to the benefits in waste management, previously mentioned, these plants, environmental and required installations, can be converted into energy generators.

Although the using already existing anaerobic digesters (such as WWTP anaerobic digesters for sewage sludge) for FW biodegradation is desirable as it increases the heat and electricity outputs, the adoption of co-digestion in these infrastructures will impose higher requirements for process control. This, in addition with the high cost of substrate transportation and the low value of the end products, develops a future scenario where $\mathrm{AD}$ is integrated with the production of value-added products. 
As an example, on one hand, FW AD can be merged with biorefineries so high-value products are produced, and, in addition, the solid wastes are treated with a subsequent AD process. On the other hand, by-products from AD process can be used to produce another high-value products, as VFA are already used to produces biopolymers, like PHA.

Author Contributions: C.M-P. conceived, designed and wrote the paper; M.C.-C. and B.Y.M.S. supervised the results.

Funding: This research received no external funding.

Conflicts of Interest: The authors declare no conflict of interest.Abbreviations

\section{Abbreviations}

$\begin{array}{ll}\text { AD } & \text { Anaerobic Digestion } \\ \text { AM } & \text { Animal Manure } \\ \text { BMP } & \text { Biochemical Methane Potential } \\ \text { CoAD } & \text { Anaerobic Co-digestion } \\ \text { EPA } & \text { Environmental Protection Agency } \\ \text { EU } & \text { European Union } \\ \text { FAO } & \text { Food and Agriculture Organization } \\ \text { FL } & \text { Food Loose } \\ \text { FSC } & \text { Food Supply Chain } \\ \text { FW } & \text { Food Waste } \\ \text { HTG } & \text { Hydrothermal Gasification } \\ \text { LCFA } & \text { Long Chain Fatty Acids } \\ \text { LPCH } & \text { Lipids, Proteins and Carbohydrates } \\ \text { OFMSW } & \text { Organic Fraction of Municipal Solid Waste } \\ \text { OM } & \text { Organic Matter } \\ \text { TBMP } & \text { Theoretical Biochemical Methane Potential } \\ \text { TS } & \text { Total Solids } \\ \text { SS } & \text { Sewage Sludge } \\ \text { VFA } & \text { Volatile Fatty Acids } \\ \text { VS } & \text { Volatile Solids } \\ \text { WWTP } & \text { Waste Water Treatment Plants }\end{array}$

\section{References}

1. Girotto, F.; Alibardi, L.; Cossu, R. Food waste generation and industrial uses: A review. Waste Manag. 2015, 45, 32-41. [CrossRef] [PubMed]

2. FAO. Food Loss Prevention in Perishable Crops—Contents; Food and Agriculture Organization: Rome, Italy, 1981.

3. Parfitt, J.; Barthel, M.; Macnaughton, S. Food waste within food supply chains: Quantification and potential for change to 2050. Philos. Trans. R. Soc. B Biol. Sci. 2010, 365, 3065-3081. [CrossRef] [PubMed]

4. Chiu, S.L.H.; Lo, I.M.C. Reviewing the anaerobic digestion and co-digestion process of food waste from the perspectives on biogas production performance and environmental impacts. Environ. Sci. Pollut. Res. 2016, 23, 24435-24450. [CrossRef] [PubMed]

5. Buzby, J.C.; Hyman, J. Total and per capita value of food loss in the United States. Food Policy 2012, 37, 561-570. [CrossRef]

6. Kojima, R.; Ishikawa, M. Prevention and Recycling of Food Wastes in Japan: Policies and Achievements; Kobe University: Kobe, Japan, 2013.

7. Health and Food Safety. Available online: https://ec.europa.eu/info/departments/health-and-food-safety_ en (accessed on 20 September 2018).

8. Monier, V.; Mudgal, S.; Escalon, V.; O'Connor, C.; Gibon, T.; Anderson, G.; Montoux, H.; Reisinger, H.; Dolley, P.; Ogilvie, S. Preparatory Study on Food Waste Across EU 27; European Commission (DG ENV) Directorate C-Industry: Brussels, Belgium, 2010. 
9. Bräutigam, K.-R.; Jörissen, J.; Priefer, C. The extent of food waste generation across EU-27: Different calculation methods and the reliability of their results. Waste Manag. Res. 2014, 32, 683-694. [CrossRef] [PubMed]

10. Nellman, C.; MacDevette, M.; Manders, T.; Eickhout, B.; Svihus, B.; Prins, A. The Environmental Food Crisis-The Environment's Role in Averting Future Food Crises; UNEP Rapid Response, U.N. Environ. Programme GRID-Arendal Nor; UNEP/Earthprint: London, UK, 2009.

11. Papargyropoulou, E.; Lozano, R.; Steinberger, J.K.; Wright, N.; bin Ujang, Z. The food waste hierarchy as a framework for the management of food surplus and food waste. J. Clean. Prod. 2014, 76, 106-115. [CrossRef]

12. Bernstad, A.; la Cour Jansen, J. Review of comparative LCAs of food waste management systems-Current status and potential improvements. Waste Manag. 2012, 32, 2439-2455. [CrossRef] [PubMed]

13. Chaya, W.; Gheewala, S.H. Life cycle assessment of MSW-to-energy schemes in Thailand. J. Clean. Prod. 2007, 15, 1463-1468. [CrossRef]

14. Khoo, H.H.; Lim, T.Z.; Tan, R.B.H. Food waste conversion options in Singapore: Environmental impacts based on an LCA perspective. Sci. Total Environ. 2010, 408, 1367-1373. [CrossRef] [PubMed]

15. Møller, J.; Boldrin, A.; Christensen, T.H. Anaerobic digestion and digestate use: Accounting of greenhouse gases and global warming contribution. Waste Manag. Res. 2009, 27, 813-824. [CrossRef] [PubMed]

16. Sustainable Management of FoodIUS EPA. Available online: https://www.epa.gov/sustainablemanagement-food (accessed on 8 January 2018).

17. The Council of The European Union. Council Directive 1999/31/EC of 26 April 1999 on the Landfill of Waste; Council of the European Union: Luxembourg, 1999; pp. 1-19.

18. The European Parliament and the Council of The European Union. DIRECTIVE 2008/98/EC of the European Parliament and of the Council of 19 November 2008 on Waste and Repealing Certain Directives; European Commission: Brussels, Belgium, 2008.

19. Cossu, R. From triangles to cycles. Waste Manag. 2009, 29, 2915-2917. [CrossRef] [PubMed]

20. Sanders, J.; Scott, E.; Weusthuis, R.; Mooibroek, H. Bio-Refinery as the Bio-Inspired Process to Bulk Chemicals. Macromol. Biosci. 2007, 7, 105-117. [CrossRef] [PubMed]

21. Uçkun Kiran, E.; Trzcinski, A.P.; Ng, W.J.; Liu, Y. Bioconversion of food waste to energy: A review. Fuel 2014, 134, 389-399. [CrossRef]

22. Koike, Y.; An, M.-Z.; Tang, Y.-Q.; Syo, T.; Osaka, N.; Morimura, S.; Kida, K. Production of fuel ethanol and methane from garbage by high-efficiency two-stage fermentation process. J. Biosci. Bioeng. 2009, 108, 508-512. [CrossRef] [PubMed]

23. Rao, M. Bioenergy conversion studies of organic fraction of MSW: Kinetic studies and gas yield-organic loading relationships for process optimisation. Bioresour. Technol. 2004, 95, 173-185. [CrossRef] [PubMed]

24. Zhang, C.; Xiao, G.; Peng, L.; Su, H.; Tan, T. The anaerobic co-digestion of food waste and cattle manure. Bioresour. Technol. 2013, 129, 170-176. [CrossRef] [PubMed]

25. Sakai, K.; Ezaki, Y. Open L-lactic acid fermentation of food refuse using thermophilic Bacillus coagulans and fluorescence in situ hybridization analysis of microflora. J. Biosci. Bioeng. 2006, 101, 457-463. [CrossRef] [PubMed]

26. Wang, Q.; Wang, X.; Wang, X.; Ma, H.; Ren, N. Bioconversion of Kitchen Garbage to Lactic Acid by Two Wild Strains of Lactobacillus Species. J. Environ. Sci. Health Part A 2005, 40, 1951-1962. [CrossRef] [PubMed]

27. Yang, S.Y.; Ji, K.S.; Baik, Y.H.; Kwak, W.S.; McCaskey, T.A. Lactic acid fermentation of food waste for swine feed. Bioresour. Technol. 2006, 97, 1858-1864. [CrossRef] [PubMed]

28. Kim, J.K.; Oh, B.R.; Shin, H.-J.; Eom, C.-Y.; Kim, S.W. Statistical optimization of enzymatic saccharification and ethanol fermentation using food waste. Process Biochem. 2008, 43, 1308-1312. [CrossRef]

29. Tang, Y.-Q.; Koike, Y.; Liu, K.; An, M.-Z.; Morimura, S.; Wu, X.-L.; Kida, K. Ethanol production from kitchen waste using the flocculating yeast Saccharomyces cerevisiae strain KF-7. Biomass Bioenergy 2008, 32, 1037-1045. [CrossRef]

30. Han, S. Biohydrogen production by anaerobic fermentation of food waste. Int. J. Hydrog. Energy 2004, 29, 569-577. [CrossRef]

31. Pan, J.; Zhang, R.; Elmashad, H.; Sun, H.; Ying, Y. Effect of food to microorganism ratio on biohydrogen production from food waste via anaerobic fermentation. Int. J. Hydrog. Energy 2008, 33, 6968-6975. [CrossRef]

32. Tuck, C.O.; Perez, E.; Horvath, I.T.; Sheldon, R.A.; Poliakoff, M. Valorization of Biomass: Deriving More Value from Waste. Science 2012, 337, 695-699. [CrossRef] [PubMed] 
33. Chiu, S.L.H.; Lo, I.M.C.; Woon, K.S.; Yan, D.Y.S. Life cycle assessment of waste treatment strategy for sewage sludge and food waste in Macau: Perspectives on environmental and energy production performance. Int. J. Life Cycle Assess. 2016, 21, 176-189. [CrossRef]

34. Zhang, C.; Su, H.; Baeyens, J.; Tan, T. Reviewing the anaerobic digestion of food waste for biogas production. Renew. Sustain. Energy Rev. 2014, 38, 383-392. [CrossRef]

35. Iacovidou, E.; Ohandja, D.-G.; Gronow, J.; Voulvoulis, N. The Household Use of Food Waste Disposal Units as a Waste Management Option: A Review. Crit. Rev. Environ. Sci. Technol. 2012, 42, 1485-1508. [CrossRef]

36. Iacovidou, E.; Ohandja, D.-G.; Voulvoulis, N. Food waste co-digestion with sewage sludge-Realising its potential in the UK. J. Environ. Manag. 2012, 112, 267-274. [CrossRef] [PubMed]

37. Straka, F.; Jenicek, P.; Zabranska, J.; Dohanyos, M.; Kuncarova, M. Anaerobic Fermentation of Biomass and Wastes with Respect to Sulfur and Nitrogen Contents in Treated Materials. In Proceedings of the 11th International Waste Management and Landifill Symposium; Environmental Sanitary Engineering Centre (CISA): Sardinia, Italy, 2007.

38. Lu, J.; Gavala, H.N.; Skiadas, I.V.; Mladenovska, Z.; Ahring, B.K. Improving anaerobic sewage sludge digestion by implementation of a hyper-thermophilic prehydrolysis step. J. Environ. Manag. 2008, 88, 881-889. [CrossRef] [PubMed]

39. Belitz, H.D.; Grosch, W.; Schieberle, P. Food Chemistry 4th Revised and Extended Edition; Springer-Verlag: Berlin/Heidelberg, Germany, 2009; pp. 315-327.

40. Christ, O.; Wilderer, P.A.; Angerhöfer, R.; Faulstich, M. Mathematical modeling of the hydrolysis of anaerobic processes. Water Sci. Technol. 2000, 41, 61-65. [CrossRef] [PubMed]

41. Carucci, G.; Carrasco, F.; Trifoni, K.; Majone, M.; Beccari, M. Anaerobic Digestion of Food Industry Wastes: Effect of Codigestion on Methane Yield. J. Environ. Eng. 2005, 131, 1037-1045. [CrossRef]

42. Kobayashi, T.; Xu, K.-Q.; Li, Y.-Y.; Inamori, Y. Evaluation of hydrogen and methane production from municipal solid wastes with different compositions of fat, protein, cellulosic materials and the other carbohydrates. Int. J. Hydrog. Energy 2012, 37, 15711-15718. [CrossRef]

43. Carlsson, M.; Holmström, D.; Bohn, I.; Bisaillon, M.; Morgan-Sagastume, F.; Lagerkvist, A. Impact of physical pre-treatment of source-sorted organic fraction of municipal solid waste on greenhouse-gas emissions and the economy in a Swedish anaerobic digestion system. Waste Manag. 2015, 38, 117-125. [CrossRef] [PubMed]

44. Naroznova, I.; Møller, J.; Scheutz, C. Characterisation of the biochemical methane potential (BMP) of individual material fractions in Danish source-separated organic household waste. Waste Manag. 2016, 50, 39-48. [CrossRef] [PubMed]

45. Agyeman, F.O.; Tao, W. Anaerobic co-digestion of food waste and dairy manure: Effects of food waste particle size and organic loading rate. J. Environ. Manag. 2014, 133, 268-274. [CrossRef] [PubMed]

46. Zhang, L.; Lee, Y.-W.; Jahng, D. Anaerobic co-digestion of food waste and piggery wastewater: Focusing on the role of trace elements. Bioresour. Technol. 2011, 102, 5048-5059. [CrossRef] [PubMed]

47. Zhang, C.; Su, H.; Tan, T. Batch and semi-continuous anaerobic digestion of food waste in a dual solid-liquid system. Bioresour. Technol. 2013, 145, 10-16. [CrossRef] [PubMed]

48. Zhang, R.; Elmashad, H.; Hartman, K.; Wang, F.; Liu, G.; Choate, C.; Gamble, P. Characterization of food waste as feedstock for anaerobic digestion. Bioresour. Technol. 2007, 98, 929-935. [CrossRef] [PubMed]

49. Li, R.; Ge, Y.; Wang, K.; Li, X.; Pang, Y. Characteristics and anaerobic digestion performances of kitchen wastes. Kezaisheng Nengyuan Renew. Energy Resour. 2010, 28, 76-80.

50. Zhang, W.; Zhang, L.; Li, A. Anaerobic co-digestion of food waste with MSW incineration plant fresh leachate: Process performance and synergistic effects. Chem. Eng. J. 2015, 259, 795-805. [CrossRef]

51. Guo, J.; Wang, W.; Liu, X.; Lian, S.; Zheng, L. Effects of thermal pre-treatment on anaerobic co-digestion of municipal biowastes at high organic loading rate. Chemosphere 2014, 101, 66-70. [CrossRef] [PubMed]

52. Meng, Y.; Li, S.; Yuan, H.; Zou, D.; Liu, Y.; Zhu, B.; Chufo, A.; Jaffar, M.; Li, X. Evaluating biomethane production from anaerobic mono- and co-digestion of food waste and floatable oil (FO) skimmed from food waste. Bioresour. Technol. 2015, 185, 7-13. [CrossRef] [PubMed]

53. Mirabella, N.; Castellani, V.; Sala, S. Current options for the valorization of food manufacturing waste: A review. J. Clean. Prod. 2014, 65, 28-41. [CrossRef]

54. Fuessl, A.; Yamamoto, M.; Schneller, A. Opportunities in Bio-Based Building Blocks for Polycondensates and Vinyl Polymers; Elsevier: New York, NY, USA, 2012; pp. 49-70. 
55. Li, X.; Chen, Y.; Zhao, S.; Chen, H.; Zheng, X.; Luo, J.; Liu, Y. Efficient production of optically pure 1 -lactic acid from food waste at ambient temperature by regulating key enzyme activity. Water Res. 2015, 70, 148-157. [CrossRef] [PubMed]

56. Hassan, M.A.; Yee, L.-N.; Yee, P.L.; Ariffin, H.; Raha, A.R.; Shirai, Y.; Sudesh, K. Sustainable production of polyhydroxyalkanoates from renewable oil-palm biomass. Biomass Bioenergy 2013, 50, 1-9. [CrossRef]

57. Sulaiman, A.; Othman, N.; Baharuddin, A.S.; Mokhtar, M.N.; Tabatabaei, M. Enhancing the Halal Food Industry by Utilizing Food Wastes to Produce Value-added Bioproducts. Procedia Soc. Behav. Sci. 2014, 121, 35-43. [CrossRef]

58. Pagliano, G.; Ventorino, V.; Panico, A.; Pepe, O. Integrated systems for biopolymers and bioenergy production from organic waste and by-products: A review of microbial processes. Biotechnol. Biofuels 2017, 10, 113. [CrossRef] [PubMed]

59. Refaat, A.A. Biofuels from Waste Materials. In Comprehensive Renewable Energy; Elsevier: New York, NY, USA, 2012; pp. 217-261. ISBN 978-0-08-087873-7.

60. Gasparatos, A.; Stromberg, P.; Takeuchi, K. Biofuels, ecosystem services and human wellbeing: Putting biofuels in the ecosystem services narrative. Agric. Ecosyst. Environ. 2011, 142, 111-128. [CrossRef]

61. Mattioli, A.; Boscaro, D.; Dalla Venezia, F.; Correale Santacroce, F.; Pezzuolo, A.; Sartori, L.; Bolzonella, D. Biogas from Residual Grass: A Territorial Approach for Sustainable Bioenergy Production. Waste Biomass Valorization 2017, 8, 2747-2756. [CrossRef]

62. Boscaro, D.; Pezzuolo, A.; Sartori, L.; Marinello, F.; Mattioli, A.; Bolzonella, D.; Grigolato, S. Evaluation of the energy and greenhouse gases impacts of grass harvested on riverbanks for feeding anaerobic digestion plants. J. Clean. Prod. 2018, 172, 4099-4109. [CrossRef]

63. Pirozzi, D.; Ausiello, A.; Strazza, R.; Trofa, M.; Zuccaro, G.; Toscano, G. Exploitation of agricultural biomasses to produce ii-generation biodiesel. Chem. Eng. Trans. 2013, 175-180. [CrossRef]

64. Canakci, M. The potential of restaurant waste lipids as biodiesel feedstocks. Bioresour. Technol. 2007, 98, 183-190. [CrossRef] [PubMed]

65. Yaakob, Z.; Mohammad, M.; Alherbawi, M.; Alam, Z.; Sopian, K. Overview of the production of biodiesel from Waste cooking oil. Renew. Sustain. Energy Rev. 2013, 18, 184-193. [CrossRef]

66. Morales-Polo, C.; Cledera-Castro, M. del M. An optimized water reuse and waste valorization method for a sustainable development of poultry slaughtering plants. Desalin. Water Treat. 2016, 57, 2702-2711. [CrossRef]

67. Alptekin, E.; Canakci, M.; Sanli, H. Biodiesel production from vegetable oil and waste animal fats in a pilot plant. Waste Manag. 2014, 34, 2146-2154. [CrossRef] [PubMed]

68. Ghanavati, H.; Nahvi, I.; Karimi, K. Organic fraction of municipal solid waste as a suitable feedstock for the production of lipid by oleaginous yeast Cryptococcus aerius. Waste Manag. 2015, 38, 141-148. [CrossRef] [PubMed]

69. Cekmecelioglu, D.; Uncu, O.N. Kinetic modeling of enzymatic hydrolysis of pretreated kitchen wastes for enhancing bioethanol production. Waste Manag. 2013, 33, 735-739. [CrossRef] [PubMed]

70. Stoeberl, M.; Werkmeister, R.; Faulstich, M.; Russ, W. Biobutanol from food wastes-fermentative production, use as biofuel an the influence on the emissions. Procedia Food Sci. 2011, 1, 1867-1874. [CrossRef]

71. Pham, T.P.T.; Kaushik, R.; Parshetti, G.K.; Mahmood, R.; Balasubramanian, R. Food waste-to-energy conversion technologies: Current status and future directions. Waste Manag. 2015, 38, 399-408. [CrossRef] [PubMed]

72. Arena, U. Process and technological aspects of municipal solid waste gasification. A review. Waste Manag. 2012, 32, 625-639. [CrossRef] [PubMed]

73. Muangrat, R.; Onwudili, J.A.; Williams, P.T. Reactions of different food classes during subcritical water gasification for hydrogen gas production. Int. J. Hydrog. Energy 2012, 37, 2248-2259. [CrossRef]

74. Lin, C.S.K.; Pfaltzgraff, L.A.; Herrero-Davila, L.; Mubofu, E.B.; Abderrahim, S.; Clark, J.H.; Koutinas, A.A.; Kopsahelis, N.; Stamatelatou, K.; et al. Food waste as a valuable resource for the production of chemicals, materials and fuels. Current situation and global perspective. Energy Environ. Sci. 2013, 6, 426. [CrossRef]

75. Hagos, K.; Zong, J.; Li, D.; Liu, C.; Lu, X. Anaerobic co-digestion process for biogas production: Progress, challenges and perspectives. Renew. Sustain. Energy Rev. 2017, 76, 1485-1496. [CrossRef]

76. O'Sullivan, C.; Rounsefell, B.; Grinham, A.; Clarke, W.; Udy, J. Anaerobic digestion of harvested aquatic weeds: Water hyacinth (Eichhornia crassipes), cabomba (Cabomba caroliniana) and salvinia (Salvinia molesta). Ecol. Eng. 2010, 36, 1459-1468. [CrossRef] 
77. Cho, J.K.; Park, S.C.; Chang, H.N. Biochemical methane potential and solid state anaerobic digestion of Korean food wastes. Bioresour. Technol. 1995, 52, 245-253. [CrossRef]

78. Chynoweth, D.P.; Turick, C.E.; Owens, J.M.; Jerger, D.E.; Peck, M.W. Biochemical methane potential of biomass and waste feedstocks. Biomass Bioenergy 1993, 5, 95-111. [CrossRef]

79. García, A.J.; Esteban, M.B.; Márquez, M.C.; Ramos, P. Biodegradable municipal solid waste: Characterization and potential use as animal feedstuffs. Waste Manag. 2005, 25, 780-787. [CrossRef] [PubMed]

80. Mata-Alvarez, J.; Llabrés, P.; Cecchi, F.; Pavan, P. Anaerobic digestion of the Barcelona central food market organic wastes: Experimental study. Bioresour. Technol. 1992, 39, 39-48. [CrossRef]

81. Nallathambi Gunaseelan, V. Anaerobic digestion of biomass for methane production: A review. Biomass Bioenergy 1997, 13, 83-114. [CrossRef]

82. Abbasi, T.; Tauseef, S.M.; Abbasi, S.A. Biogas Energy; Springer: New York, NY, 2012; ISBN 978-1-4614-1039-3.

83. Esposito, G.; Frunzo, L.; Giordano, A.; Liotta, F.; Panico, A.; Pirozzi, F. Anaerobic co-digestion of organic wastes. Rev. Environ. Sci. Biotechnol. 2012, 11, 325-341. [CrossRef]

84. Zhang, L.; Jahng, D. Long-term anaerobic digestion of food waste stabilized by trace elements. Waste Manag. 2012, 32, 1509-1515. [CrossRef] [PubMed]

85. Appels, L.; Assche, A.V.; Willems, K.; Degrève, J.; Impe, J.V.; Dewil, R. Peracetic acid oxidation as an alternative pre-treatment for the anaerobic digestion of waste activated sludge. Bioresour. Technol. 2011, 102, 4124-4130. [CrossRef] [PubMed]

86. Gujer, W.; Zehnder, A.J.R. Conversion Processes in Anaerobic Digestion. Water Sci. Technol. 1983, 15, $127-167$. [CrossRef]

87. Huete, E. Estudio Comparativo de la Digestión Anaerobia Mesófila y Termófila de Fangos Urbanos. Estado del arte, Parámetros de Operación y Modelado Matemático del Sistema; Universidad de Navarra: San Sebastán, Spain, 2007.

88. Coelho, N.M.G.; Droste, R.L.; Kennedy, K.J. Evaluation of continuous mesophilic, thermophilic and temperature phased anaerobic digestion of microwaved activated sludge. Water Res. 2011, 45, 2822-2834. [CrossRef] [PubMed]

89. Veeken, A.; Hamelers, B. Effect of temperature on hydrolysis rates of selected biowaste components. Bioresour. Technol. 1999, 69, 249-254. [CrossRef]

90. Hawkes, F.R. The biochemistry of anaerobic digestion. In Biomethane: Production and Uses; Roger Bowskil Printing Ltd.: Exeter, UK, 1980; pp. 41-60.

91. Hill, C.G. An Introduction to Chemical Engineering Kinetics \& Reactor Design; Wiley: New York, NY, USA, 1977; ISBN 978-0-471-39609-3.

92. Palmowski, L.M.; Müller, J.A.; Palmowski, L.M.; Müller, J.A. Influence of the size reduction of organic waste on their anaerobic digestion. Water Sci. Technol. 2000, 41, 155-162. [CrossRef] [PubMed]

93. Lettinga, G.; Field, J.; van Lier, J.; Zeeman, G.; Huishoff Pol, L.W. Advanced anaerobic wastewater treatment in the near future. Water Sci. Technol. 1997, 35. [CrossRef]

94. Angelidaki, I.; Sanders, W. Assessment of the anaerobic biodegradability of macropollutants. Rev. Environ. Sci. Biotechnol. 2004, 3, 117-129. [CrossRef]

95. Izumi, K.; Okishio, Y.; Nagao, N.; Niwa, C.; Yamamoto, S.; Toda, T. Effects of particle size on anaerobic digestion of food waste. Int. Biodeterior. Biodegrad. 2010, 64, 601-608. [CrossRef]

96. Kim, I.S.; Kim, D.H.; Hyun, S.H. Effect of particle size and sodium ion concentration on anaerobic thermophilic food waste digestion. Water Sci. Technol. 2000, 41, 67-73. [CrossRef] [PubMed]

97. Sanders, W.T.M. Anaerobic Hydrolysis during Digestion of Complex Substrates; Wageningen University: Wageningen, The Netherlands, 2001.

98. Eastman, J.A.; Ferguson, J.F. Solubilization of Particulate Organic Carbon during the Acid Phase of Anaerobic Digestion. Water Pollut. Control Fed. 1981, 53, 352-366.

99. Sanders, W.T.M.; Geerink, M.; Lettinga, G. Anaerobic hydrolysis kinetics of particulate substrates. Water Sci. Technol. 2000, 41, 17-24. [CrossRef] [PubMed]

100. Vavilin, V.A.; Rytov, S.V.; Lokshina, L.Y. A description of hydrolysis kinetics in anaerobic degradation of particulate organic matter. Bioresour. Technol. 1996, 56, 229-237. [CrossRef]

101. Cadavid-Rodríguez, L.S.; Horan, N. Methane production and hydrolysis kinetics in the anaerobic degradation of wastewater screenings. Water Sci. Technol. 2013, 68, 413. [CrossRef] [PubMed]

102. Gunaseelan, V.N. Biochemical methane potential of fruits and vegetable solid waste feedstocks. Biomass Bioenergy 2004, 26, 389-399. [CrossRef] 
103. Jokela, J.P.Y.; Vavilin, V.A.; Rintala, J.A. Hydrolysis rates, methane production and nitrogen solubilisation of grey waste components during anaerobic degradation. Bioresour. Technol. 2005, 96, 501-508. [CrossRef] [PubMed]

104. Vavilin, V.A.; Fernandez, B.; Palatsi, J.; Flotats, X. Hydrolysis kinetics in anaerobic degradation of particulate organic material: An overview. Waste Manag. 2008, 28, 939-951. [CrossRef] [PubMed]

105. Buffiere, P.; Loisel, D.; Bernet, N.; Delgenes, J.-P. Towards new indicators for the prediction of solid waste anaerobic digestion properties. Water Sci. Technol. 2006, 53, 233-241. [CrossRef] [PubMed]

106. Tong, X.; Smith, L.H.; McCarty, P.L. Methane fermentation of selected lignocellulosic materials. Biomass 1990, 21, 239-255. [CrossRef]

107. Panico, A.; d'Antonio, G.; Esposito, G.; Frunzo, L.; Iodice, P.; Pirozzi, F.; Panico, A.; d'Antonio, G.; Esposito, G.; Frunzo, L.; et al. The Effect of Substrate-Bulk Interaction on Hydrolysis Modeling in Anaerobic Digestion Process. Sustainability 2014, 6, 8348-8363. [CrossRef]

108. Yeh, A.-I.; Huang, Y.-C.; Chen, S.H. Effect of particle size on the rate of enzymatic hydrolysis of cellulose. Carbohydr. Polym. 2010, 79, 192-199. [CrossRef]

109. Hobson, P.N. A model of some aspects of microbial degradation of particulate substrates. J. Ferment. Technol. 1987, 65, 431-439. [CrossRef]

110. Kwietniewska, E.; Tys, J. Process characteristics, inhibition factors and methane yields of anaerobic digestion process, with particular focus on microalgal biomass fermentation. Renew. Sustain. Energy Rev. 2014, 34, 491-500. [CrossRef]

111. Pavlostathis, S.G.; Giraldo-Gomez, E. Kinetics of anaerobic treatment: A critical review. Crit. Rev. Environ. Control 1991, 21, 411-490. [CrossRef]

112. Sánchez, E.; Borja, R.; Weiland, P.; Travieso, L.; Martín, A. Effect of substrate concentration and temperature on the anaerobic digestion of piggery waste in a tropical climate. Process Biochem. 2001, 37, 483-489. [CrossRef]

113. Elmashad, H. Effect of temperature and temperature fluctuation on thermophilic anaerobic digestion of cattle manure. Bioresour. Technol. 2004, 95, 191-201. [CrossRef] [PubMed]

114. Kim, J.K.; Oh, B.R.; Chun, Y.N.; Kim, S.W. Effects of temperature and hydraulic retention time on anaerobic digestion of food waste. J. Biosci. Bioeng. 2006, 102, 328-332. [CrossRef] [PubMed]

115. Jules, B.; van, L.; Salih, R.; Gatze, L. High-rate anaerobic wastewater treatment under psychrophilic and thermophilic conditions. Water Sci. Technol. 1997, 35. [CrossRef]

116. Gallert, C.; Winter, J. Mesophilic and thermophilic anaerobic digestion of source-sorted organic wastes: Effect of ammonia on glucose degradation and methane production. Appl. Microbiol. Biotechnol. 1997, 48, 405-410. [CrossRef]

117. Schink, B.; Stams, A.J.M. Syntrophism Among Prokaryotes. In The Prokaryotes; Rosenberg, E., DeLong, E.F., Lory, S., Stackebrandt, E., Thompson, F., Eds.; Springer: Berlin/Heidelberg, Germany, 2013; pp. 471-493. ISBN 978-3-642-30122-3.

118. Xu, Z.; Zhao, M.; Miao, H.; Huang, Z.; Gao, S.; Ruan, W. In situ volatile fatty acids influence biogas generation from kitchen wastes by anaerobic digestion. Bioresour. Technol. 2014, 163, 186-192. [CrossRef] [PubMed]

119. Buyukkamaci, N.; Filibeli, A. Volatile fatty acid formation in an anaerobic hybrid reactor. Process Biochem. 2004, 39, 1491-1494. [CrossRef]

120. Demirel, B.; Scherer, P. The roles of acetotrophic and hydrogenotrophic methanogens during anaerobic conversion of biomass to methane: A review. Rev. Environ. Sci. Biotechnol. 2008, 7, 173-190. [CrossRef]

121. Horiuchi, J.; Shimizu, T.; Kanno, T.; Kobayashi, M. Dynamic behavior in response to $\mathrm{pH}$ shift during anaerobic acidogenesis with a chemostat culture. Biotechnol. Tech. 1999, 13, 155-157. [CrossRef]

122. Fang, H.H.P.; Liu, H. Effect of $\mathrm{pH}$ on hydrogen production from glucose by a mixed culture. Bioresour. Technol. 2002, 82, 87-93. [CrossRef]

123. Horiuchi, J.-I.; Shimizu, T.; Tada, K.; Kanno, T.; Kobayashi, M. Selective production of organic acids in anaerobic acid reactor by $\mathrm{pH}$ control. Bioresour. Technol. 2002, 82, 209-213. [CrossRef]

124. Li, Y.; Park, S.Y.; Zhu, J. Solid-state anaerobic digestion for methane production from organic waste. Renew. Sustain. Energy Rev. 2011, 15, 821-826. [CrossRef]

125. Wang, X.; Yang, G.; Feng, Y.; Ren, G.; Han, X. Optimizing feeding composition and carbon-nitrogen ratios for improved methane yield during anaerobic co-digestion of dairy, chicken manure and wheat straw. Bioresour. Technol. 2012, 120, 78-83. [CrossRef] [PubMed] 
126. Karthikeyan, O.P.; Visvanathan, C. Effect of $\mathrm{C} / \mathrm{N}$ ratio and ammonia-N accumulation in a pilot-scale thermophilic dry anaerobic digester. Bioresour. Technol. 2012, 113, 294-302. [CrossRef]

127. Walker, M.; Iyer, K.; Heaven, S.; Banks, C.J. Ammonia removal in anaerobic digestion by biogas stripping: An evaluation of process alternatives using a first order rate model based on experimental findings. Chem. Eng. J. 2011, 178, 138-145. [CrossRef]

128. Yenigün, O.; Demirel, B. Ammonia inhibition in anaerobic digestion: A review. Process Biochem. 2013, 48, 901-911. [CrossRef]

129. Park, S.; Li, Y. Evaluation of methane production and macronutrient degradation in the anaerobic co-digestion of algae biomass residue and lipid waste. Bioresour. Technol. 2012, 111, 42-48. [CrossRef] [PubMed]

130. Yen, H.; Brune, D. Anaerobic co-digestion of algal sludge and waste paper to produce methane. Bioresour. Technol. 2007, 98, 130-134. [CrossRef] [PubMed]

131. Banks, C.J.; Humphreys, P.N. The anaerobic treatment of a ligno-cellulosic substrate offering little natural pH buffering capacity. Water Sci. Technol. 1998, 38. [CrossRef]

132. Wang, Q.; Peng, L.; Su, H. The effect of a buffer function on the semi-continuous anaerobic digestion. Bioresour. Technol. 2013, 139, 43-49. [CrossRef] [PubMed]

133. Chen, Y.; Cheng, J.J.; Creamer, K.S. Inhibition of anaerobic digestion process: A review. Bioresour. Technol. 2008, 99, 4044-4064. [CrossRef] [PubMed]

134. Lauterböck, B.; Ortner, M.; Haider, R.; Fuchs, W. Counteracting ammonia inhibition in anaerobic digestion by removal with a hollow fiber membrane contactor. Water Res. 2012, 46, 4861-4869. [CrossRef] [PubMed]

135. Sprott, G.D.; Patel, G.B. Ammonia toxicity in pure cultures of methanogenic bacteria. Syst. Appl. Microbiol. 1986, 7, 358-363. [CrossRef]

136. Webb, A.R.; Hawkes, F.R. The anaerobic digestion of poultry manure: Variation of gas yield with influent concentration and ammonium-nitrogen levels. Agric. Wastes 1985, 14, 135-156. [CrossRef]

137. Fernandes, T.V.; Keesman, K.J.; Zeeman, G.; van Lier, J.B. Effect of ammonia on the anaerobic hydrolysis of cellulose and tributyrin. Biomass Bioenergy 2012, 47, 316-323. [CrossRef]

138. Chen, H.; Wang, W.; Xue, L.; Chen, C.; Liu, G.; Zhang, R. Effects of Ammonia on Anaerobic Digestion of Food Waste: Process Performance and Microbial Community. Energy Fuels 2016, 30, 5749-5757. [CrossRef]

139. Abouelenien, F.; Fujiwara, W.; Namba, Y.; Kosseva, M.; Nishio, N.; Nakashimada, Y. Improved methane fermentation of chicken manure via ammonia removal by biogas recycle. Bioresour. Technol. 2010, 101, 6368-6373. [CrossRef] [PubMed]

140. Lahav, O.; Schwartz, Y.; Nativ, P.; Gendel, Y. Sustainable removal of ammonia from anaerobic-lagoon swine waste effluents using an electrochemically-regenerated ion exchange process. Chem. Eng. J. 2013, 218, 214-222. [CrossRef]

141. Park, J.; Jin, H.-F.; Lim, B.-R.; Park, K.-Y.; Lee, K. Ammonia removal from anaerobic digestion effluent of livestock waste using green alga Scenedesmus sp. Bioresour. Technol. 2010, 101, 8649-8657. [CrossRef] [PubMed]

142. Zhang, L.; Jahng, D. Enhanced anaerobic digestion of piggery wastewater by ammonia stripping: Effects of alkali types. J. Hazard. Mater. 2010, 182, 536-543. [CrossRef] [PubMed]

143. Ahn, Y.-H. Sustainable nitrogen elimination biotechnologies: A review. Process Biochem. 2006, 41, $1709-1721$. [CrossRef]

144. Guštin, S.; Marinšek-Logar, R. Effect of $\mathrm{pH}$, temperature and air flow rate on the continuous ammonia stripping of the anaerobic digestion effluent. Process Saf. Environ. Prot. 2011, 89, 61-66. [CrossRef]

145. Lin, L.; Yuan, S.; Chen, J.; Xu, Z.; Lu, X. Removal of ammonia nitrogen in wastewater by microwave radiation. J. Hazard. Mater. 2009, 161, 1063-1068. [CrossRef] [PubMed]

146. Sabumon, P.C. Anaerobic ammonia removal in presence of organic matter: A novel route. J. Hazard. Mater. 2007, 149, 49-59. [CrossRef] [PubMed]

147. Uludag-Demirer, S.; Demirer, G.N.; Chen, S. Ammonia removal from anaerobically digested dairy manure by struvite precipitation. Process Biochem. 2005, 40, 3667-3674. [CrossRef]

148. Palatsi, J.; Affes, R.; Fernandez, B.; Pereira, M.A.; Alves, M.M.; Flotats, X. Influence of adsorption and anaerobic granular sludge characteristics on long chain fatty acids inhibition process. Water Res. 2012, 46, 5268-5278. [CrossRef] [PubMed]

149. Zonta, Ž.; Alves, M.M.; Flotats, X.; Palatsi, J. Modelling inhibitory effects of long chain fatty acids in the anaerobic digestion process. Water Res. 2013, 47, 1369-1380. [CrossRef] [PubMed] 
150. Oh, S.T.; Martin, A.D. Long chain fatty acids degradation in anaerobic digester: Thermodynamic equilibrium consideration. Process Biochem. 2010, 45, 335-345. [CrossRef]

151. Cuetos, M.J.; Gómez, X.; Otero, M.; Morán, A. Anaerobic digestion of solid slaughterhouse waste (SHW) at laboratory scale: Influence of co-digestion with the organic fraction of municipal solid waste (OFMSW). Biochem. Eng. J. 2008, 40, 99-106. [CrossRef]

152. Neves, L.; Oliveira, R.; Alves, M.M. Anaerobic co-digestion of coffee waste and sewage sludge. Waste Manag. 2006, 26, 176-181. [CrossRef] [PubMed]

153. Sánchez, M.; Gomez, X.; Barriocanal, G.; Cuetos, M.J.; Morán, A. Assessment of the stability of livestock farm wastes treated by anaerobic digestion. Int. Biodeterior. Biodegrad. 2008, 62, 421-426. [CrossRef]

154. Masse, L.; Massé, D.I.; Kennedy, K.J.; Chou, S.P. Neutral fat hydrolysis and long-chain fatty acid oxidation during anaerobic digestion of slaughterhouse wastewater. Biotechnol. Bioeng. 2002, 79, 43-52. [CrossRef] [PubMed]

155. Palatsi, J.; Laureni, M.; Andrés, M.V.; Flotats, X.; Nielsen, H.B.; Angelidaki, I. Strategies for recovering inhibition caused by long chain fatty acids on anaerobic thermophilic biogas reactors. Bioresour. Technol. 2009, 100, 4588-4596. [CrossRef] [PubMed]

156. Lalman, J.; Bagley, D.M. Effects of C18 long chain fatty acids on glucose, butyrate and hydrogen degradation. Water Res. 2002, 36, 3307-3313. [CrossRef]

157. Cavaleiro, A.J.; Pereira, M.A.; Alves, M. Enhancement of methane production from long chain fatty acid based effluents. Bioresour. Technol. 2008, 99, 4086-4095. [CrossRef] [PubMed]

158. Facchin, V.; Cavinato, C.; Fatone, F.; Pavan, P.; Cecchi, F.; Bolzonella, D. Effect of trace element supplementation on the mesophilic anaerobic digestion of foodwaste in batch trials: The influence of inoculum origin. Biochem. Eng. J. 2013, 70, 71-77. [CrossRef]

159. Schattauer, A.; Abdoun, E.; Weiland, P.; Plöchl, M.; Heiermann, M. Abundance of trace elements in demonstration biogas plants. Biosyst. Eng. 2011, 108, 57-65. [CrossRef]

160. Climenhaga, M.A.; Banks, C.J. Anaerobic digestion of catering wastes: Effect of micronutrients and retention time. Water Sci. Technol. 2008, 57, 687. [CrossRef] [PubMed]

161. Dai, X.; Duan, N.; Dong, B.; Dai, L. High-solids anaerobic co-digestion of sewage sludge and food waste in comparison with mono digestions: Stability and performance. Waste Manag. 2013, 33, 308-316. [CrossRef] [PubMed]

162. Jackson-Moss, C.A.; Duncan, J.R.; Cooper, D.R. The effect of calcium on anaerobic digestion. Biotechnol. Lett. 1989, 11, 219-224. [CrossRef]

163. Huang, J.; Pinder, K.L. Effects of calcium on development of anaerobic acidogenic biofilms. Biotechnol. Bioeng. 1995, 45, 212-218. [CrossRef] [PubMed]

164. Kugelman, I.J.; Mccarty, P.L. Cation Toxicity and Stimulation in Anaerobic Waste Treatment. Water Pollut. Control Fed. 1965, 37, 97-116.

165. Buswell, A.M.; Mueller, H.F. Mechanism of Methane Fermentation. Ind. Eng. Chem. 1952, 44, 550-552. [CrossRef]

166. Boyle, W.C. Energy recovery from sanitary landfills-A review. In Microbial Energy Conversion; Elsevier: New York, NY, USA, 1977; pp. 119-138. ISBN 978-0-08-021791-8.

167. Standard, V.D.I. VDI 4630 Fermentation of Organic Materials-Characterisation of the Substrate, Sampling, Collection of Material Data, Fermentation Tests; The Association of German Engineers (VDI): Düsseldorf, Germany, 2006; p. 92.

168. Chandra, R.; Takeuchi, H.; Hasegawa, T. Methane production from lignocellulosic agricultural crop wastes: A review in context to second generation of biofuel production. Renew. Sustain. Energy Rev. 2012, 16, 1462-1476. [CrossRef]

169. Wagner, A.O.; Lins, P.; Malin, C.; Reitschuler, C.; Illmer, P. Impact of protein-, lipid- and cellulose-containing complex substrates on biogas production and microbial communities in batch experiments. Sci. Total Environ. 2013, 458-460, 256-266. [CrossRef] [PubMed]

170. Yang, L.; Xu, F.; Ge, X.; Li, Y. Challenges and strategies for solid-state anaerobic digestion of lignocellulosic biomass. Renew. Sustain. Energy Rev. 2015, 44, 824-834. [CrossRef]

171. Mei, Z.; Liu, X.; Huang, X.; Li, D.; Yan, Z.; Yuan, Y.; Huang, Y. Anaerobic Mesophilic Codigestion of Rice Straw and Chicken Manure: Effects of Organic Loading Rate on Process Stability and Performance. Appl. Biochem. Biotechnol. 2016, 179, 846-862. [CrossRef] [PubMed] 
172. Kallistova, A.Y.; Goel, G.; Nozhevnikova, A.N. Microbial diversity of methanogenic communities in the systems for anaerobic treatment of organic waste. Microbiology 2014, 83, 462-483. [CrossRef]

173. Schnürer, A.; Nordberg, A. Ammonia, a selective agent for methane production by syntrophic acetate oxidation at mesophilic temperature. Water Sci. Technol. 2008, 57, 735. [CrossRef] [PubMed]

174. Angelidaki, I.; Ahring, B.K. Effects of free long-chain fatty acids on thermophilic anaerobic digestion. Appl. Microbiol. Biotechnol. 1992, 37. [CrossRef]

175. Chow, W.L.; Chan, Y.J.; Chong, M.F. A new energy source from the anaerobic co-digestion (acd) treatment of oleo chemical effluent with glycerin pitch: Co-digestion of Oleo Chemical Effluent with Glycerin Pitch. Asia-Pac. J. Chem. Eng. 2015. [CrossRef]

176. Fernández, A.; Sánchez, A.; Font, X. Anaerobic co-digestion of a simulated organic fraction of municipal solid wastes and fats of animal and vegetable origin. Biochem. Eng. J. 2005, 26, 22-28. [CrossRef]

177. Lesteur, M.; Bellon-Maurel, V.; Gonzalez, C.; Latrille, E.; Roger, J.M.; Junqua, G.; Steyer, J.P. Alternative methods for determining anaerobic biodegradability: A review. Process Biochem. 2010, 45, 431-440. [CrossRef]

178. Angelidaki, I.; Alves, M.; Bolzonella, D.; Borzacconi, L.; Campos, J.L.; Guwy, A.J.; Kalyuzhnyi, S.; Jenicek, P.; van Lier, J.B. Defining the biomethane potential (BMP) of solid organic wastes and energy crops: A proposed protocol for batch assays. Water Sci. Technol. 2009, 59, 927. [CrossRef] [PubMed]

179. Owens, J.M.; Chynoweth, D.P. Biochemical Methane Potential of Municipal Solid Waste (MSW) Components. Water Sci. Technol. 1993, 27, 1-14. [CrossRef]

180. Møller, H.B.; Sommer, S.G.; Ahring, B.K. Methane productivity of manure, straw and solid fractions of manure. Biomass Bioenergy 2004, 26, 485-495. [CrossRef]

181. Triolo, J.M.; Sommer, S.G.; Møller, H.B.; Weisbjerg, M.R.; Jiang, X.Y. A new algorithm to characterize biodegradability of biomass during anaerobic digestion: Influence of lignin concentration on methane production potential. Bioresour. Technol. 2011, 102, 9395-9402. [CrossRef] [PubMed]

182. Ferris, D.A.; Flores, R.A.; Shanklin, C.W.; Whitworth, M.K. Proximate Analysis of Food Service Wastes. Appl. Eng. Agric. 1995, 11, 567-572. [CrossRef]

183. la Cour Jansen, J.; Gruvberger, C.; Hanner, N.; Aspegren, H.; Svärd, A. Digestion of sludge and organic waste in the sustainability concept for Malmö, Sweden. Water Sci. Technol. 2004, 49, 163-169. [CrossRef] [PubMed]

184. Redondas, V.; Gómez, X.; García, S.; Pevida, C.; Rubiera, F.; Morán, A.; Pis, J.J. Hydrogen production from food wastes and gas post-treatment by $\mathrm{CO}_{2}$ adsorption. Waste Manag. 2012, 32, 60-66. [CrossRef] [PubMed]

185. Zhang, B.; Zhang, L.-L.; Zhang, S.-C.; Shi, H.-Z.; Cai, W.-M. The Influence of pH on Hydrolysis and Acidogenesis of Kitchen Wastes in Two-phase Anaerobic Digestion. Environ. Technol. 2005, 26, 329-340. [CrossRef] [PubMed]

186. Sosnowski, P.; Klepacz-Smolka, A.; Kaczorek, K.; Ledakowicz, S. Kinetic investigations of methane co-fermentation of sewage sludge and organic fraction of municipal solid wastes. Bioresour. Technol. 2008, 99, 5731-5737. [CrossRef] [PubMed]

187. Wang, X.; Zhao, Y. A bench scale study of fermentative hydrogen and methane production from food waste in integrated two-stage process. Int. J. Hydrog. Energy 2009, 34, 245-254. [CrossRef]

188. Banks, C.J.; Chesshire, M.; Heaven, S.; Arnold, R. Anaerobic digestion of source-segregated domestic food waste: Performance assessment by mass and energy balance. Bioresour. Technol. 2011, 102, 612-620. [CrossRef] [PubMed]

189. Kim, H.-W.; Han, S.-K.; Shin, H.-S. The optimisation of food waste addition as a co-substrate in anaerobic digestion of sewage sludge. Waste Manag. Res. 2003, 21, 515-526. [CrossRef] [PubMed]

190. Li, R.; Chen, S.; Li, X. Anaerobic Co-digestion of Kitchen Waste and Cattle Manure for Methane Production. Energy Sour. Part Recovery Util. Environ. Eff. 2009, 31, 1848-1856. [CrossRef]

191. Cuetos, M.J.; Gómez, X.; Otero, M.; Morán, A. Anaerobic digestion and co-digestion of slaughterhouse waste (SHW): Influence of heat and pressure pre-treatment in biogas yield. Waste Manag. 2010, 30, 1780-1789. [CrossRef] [PubMed]

192. Heo, N.H.; Park, S.C.; Kang, H. Effects of Mixture Ratio and Hydraulic Retention Time on Single-Stage Anaerobic Co-digestion of Food Waste and Waste Activated Sludge. J. Environ. Sci. Health Part A 2004, 39, 1739-1756. [CrossRef]

193. Callaghan, F.J.; Wase, D.A.J.; Thayanithy, K.; Forster, C.F. Continuous co-digestion of cattle slurry with fruit and vegetable wastes and chicken manure. Biomass Bioenergy 2002, 22, 71-77. [CrossRef] 
194. El-Mashad, H.M.; Zhang, R. Biogas production from co-digestion of dairy manure and food waste. Bioresour. Technol. 2010, 101, 4021-4028. [CrossRef] [PubMed]

195. Steffen, R.; Szolar, O.; Braun, R. Feedstocks for Anaerobic Digestion; University of Agricultural Science: Vienna, India, 1998.

196. Neves, L.; Oliveira, R.; Alves, M.M. Co-digestion of cow manure, food waste and intermittent input of fat. Bioresour. Technol. 2009, 100, 1957-1962. [CrossRef] [PubMed]

197. Neves, L.; Oliveira, R.; Alves, M.M. Fate of LCFA in the co-digestion of cow manure, food waste and discontinuous addition of oil. Water Res. 2009, 43, 5142-5150. [CrossRef] [PubMed]

198. Cavinato, C.; Fatone, F.; Bolzonella, D.; Pavan, P. Thermophilic anaerobic co-digestion of cattle manure with agro-wastes and energy crops: Comparison of pilot and full scale experiences. Bioresour. Technol. 2010, 101, 545-550. [CrossRef] [PubMed]

199. Shah, F.A.; Mahmood, Q.; Rashid, N.; Pervez, A.; Raja, I.A.; Shah, M.M. Co-digestion, pretreatment and digester design for enhanced methanogenesis. Renew. Sustain. Energy Rev. 2015, 42, 627-642. [CrossRef]

200. Astals, S.; Batstone, D.J.; Mata-Alvarez, J.; Jensen, P.D. Identification of synergistic impacts during anaerobic co-digestion of organic wastes. Bioresour. Technol. 2014, 169, 421-427. [CrossRef] [PubMed]

201. Astals, S.; Ariso, M.; Galí, A.; Mata-Alvarez, J. Co-digestion of pig manure and glycerine: Experimental and modelling study. J. Environ. Manag. 2011, 92, 1091-1096. [CrossRef] [PubMed]

202. Holm-Nielsen, J.B.; Al Seadi, T.; Oleskowicz-Popiel, P. The future of anaerobic digestion and biogas utilization. Bioresour. Technol. 2009, 100, 5478-5484. [CrossRef] [PubMed]

203. Jagadabhi, P.S.; Lehtomäki, A.; Rintala, J. Co-Digestion of grass silage and cow manure in a cstr by re-circulation of alkali treated solids of the digestate. Environ. Technol. 2008, 29, 1085-1093. [CrossRef] [PubMed]

204. Mata-Alvarez, J.; Dosta, J.; Romero-Güiza, M.S.; Fonoll, X.; Peces, M.; Astals, S. A critical review on anaerobic co-digestion achievements between 2010 and 2013. Renew. Sustain. Energy Rev. 2014, 36, 412-427. [CrossRef]

205. Mata-Alvarez, J.; Dosta, J.; Macé, S.; Astals, S. Codigestion of solid wastes: A review of its uses and perspectives including modeling. Crit. Rev. Biotechnol. 2011, 31, 99-111. [CrossRef] [PubMed]

206. Mata-Alvarez, J.; Macé, S.; Llabrés, P. Anaerobic digestion of organic solid wastes. An overview of research achievements and perspectives. Bioresour. Technol. 2000, 74, 3-16. [CrossRef]

207. Cabbai, V.; Ballico, M.; Aneggi, E.; Goi, D. BMP tests of source selected OFMSW to evaluate anaerobic codigestion with sewage sludge. Waste Manag. 2013, 33, 1626-1632. [CrossRef] [PubMed]

208. Astals, S.; Nolla-Ardèvol, V.; Mata-Alvarez, J. Anaerobic co-digestion of pig manure and crude glycerol at mesophilic conditions: Biogas and digestate. Bioresour. Technol. 2012, 110, 63-70. [CrossRef] [PubMed]

209. Bolzonella, D.; Battistoni, P.; Susini, C.; Cecchi, F. Anaerobic codigestion of waste activated sludge and OFMSW: The experiences of Viareggio and Treviso plants (Italy). Water Sci. Technol. 2006, 53, $203-211$. [CrossRef] [PubMed]

210. Haider, M.R.; Zeshan; Yousaf, S.; Malik, R.N.; Visvanathan, C. Effect of mixing ratio of food waste and rice husk co-digestion and substrate to inoculum ratio on biogas production. Bioresour. Technol. 2015, 190, 451-457. [CrossRef] [PubMed]

211. Yong, Z.; Dong, Y.; Zhang, X.; Tan, T. Anaerobic co-digestion of food waste and straw for biogas production. Renew. Energy 2015, 78, 527-530. [CrossRef]

212. Chen, X.; Romano, R.T.; Zhang, R. Anaerobic digestion of food wastes for biogas production. Int. J. Agric. Biol. Eng. 2010, 3, 61-72.

213. Bouallagui, H.; Rachdi, B.; Gannoun, H.; Hamdi, M. Mesophilic and thermophilic anaerobic co-digestion of abattoir wastewater and fruit and vegetable waste in anaerobic sequencing batch reactors. Biodegradation 2009, 20, 401-409. [CrossRef] [PubMed]

214. Fernandez, J.; Perez, M.; Romero, L. Effect of substrate concentration on dry mesophilic anaerobic digestion of organic fraction of municipal solid waste (OFMSW). Bioresour. Technol. 2008, 99, 6075-6080. [CrossRef] [PubMed]

215. Fernández, J.; Pérez, M.; Romero, L.I. Kinetics of mesophilic anaerobic digestion of the organic fraction of municipal solid waste: Influence of initial total solid concentration. Bioresour. Technol. 2010, 101, 6322-6328. [CrossRef] [PubMed]

216. Mottet, A.; François, E.; Latrille, E.; Steyer, J.P.; Déléris, S.; Vedrenne, F.; Carrère, H. Estimating anaerobic biodegradability indicators for waste activated sludge. Chem. Eng. J. 2010, 160, 488-496. [CrossRef] 
217. Hartmann, H.; Angelidaki, I.; Ahring, B.K. Co-digestion of the organic fraction of municipal waste with other waste types. In Biomethanization of the Organic Fraction of Municipal Solid Wastes; IWA Publishing: London, UK, 2002.

218. Heo, N.H.; Park, S.C.; Lee, J.S.; Kang, H.; Park, D.H. Single-Stage Anaerobic Codigestion for Mixture Wastes of Simulated Korean Food Waste and Waste Activated Sludge. In Biotechnology for Fuels and Chemicals; Davison, B.H., Lee, J.W., Finkelstein, M., McMillan, J.D., Eds.; Humana Press: Totowa, NJ, USA, 2003; pp. 567-579. ISBN 978-1-4612-6592-4.

219. Sosnowski, P.; Wieczorek, A.; Ledakowicz, S. Anaerobic co-digestion of sewage sludge and organic fraction of municipal solid wastes. Adv. Environ. Res. 2003, 7, 609-616. [CrossRef]

220. Kayhanian, M.; Hardy, S. The impact of four design parameters on the performance of a high-solids anaerobic digestion of municipal solid waste for fuel gas production. Environ. Technol. 1994, 15, 557-567. [CrossRef]

221. Voulvoulis, N. Water and sanitation provision in a low carbon society: The need for a systems approach. J. Renew. Sustain. Energy 2012, 4, 041403. [CrossRef]

222. Murto, M.; Björnsson, L.; Mattiasson, B. Impact of food industrial waste on anaerobic co-digestion of sewage sludge and pig manure. J. Environ. Manag. 2004, 70, 101-107. [CrossRef]

223. Stroot, P. Anaerobic codigestion of municipal solid waste and biosolids under various mixing conditions-I. digester performance. Water Res. 2001, 35, 1804-1816. [CrossRef]

224. Bolzonella, D.; Innocenti, L.; Pavan, P.; Traverso, P.; Cecchi, F. Semi-dry thermophilic anaerobic digestion of the organic fraction of municipal solid waste: Focusing on the start-up phase. Bioresour. Technol. 2003, 86, 123-129. [CrossRef]

225. Purcell, B.; Stentiford, E.I. Co-digestion-Enhancing recovery of organic waste. Orbit Artic. 2006, 1, 1-6.

226. Dohányos, M.; Zábranská, J.; Kutil, J.; Jeníek, P. Improvement of anaerobic digestion of sludge. Water Sci. Technol. 2004, 49, 89-96. [CrossRef] [PubMed]

227. Arnaiz, C.; Gutierrez, J.C.; Lebrato, J. Biomass stabilization in the anaerobic digestion of wastewater sludges. Bioresour. Technol. 2006, 97, 1179-1184. [CrossRef] [PubMed]

228. Bougrier, C.; Carrère, H.; Delgenès, J.P. Solubilisation of waste-activated sludge by ultrasonic treatment. Chem. Eng. J. 2005, 106, 163-169. [CrossRef]

229. Lafitte-Trouqué, S.; Forster, C. The use of ultrasound and $\gamma$-irradiation as pre-treatments for the anaerobic digestion of waste activated sludge at mesophilic and thermophilic temperatures. Bioresour. Technol. 2002, 84, 113-118. [CrossRef]

230. Zhang, P.; Zhang, G.; Wang, W. Ultrasonic treatment of biological sludge: Floc disintegration, cell lysis and inactivation. Bioresour. Technol. 2007, 98, 207-210. [CrossRef] [PubMed]

231. Eskicioglu, C.; Prorot, A.; Marin, J.; Droste, R.L.; Kennedy, K.J. Synergetic pretreatment of sewage sludge by microwave irradiation in presence of $\mathrm{H} 2 \mathrm{O} 2$ for enhanced anaerobic digestion. Water Res. 2008, 42, 4674-4682. [CrossRef] [PubMed]

232. Khalid, A.; Arshad, M.; Anjum, M.; Mahmood, T.; Dawson, L. The anaerobic digestion of solid organic waste. Waste Manag. 2011, 31, 1737-1744. [CrossRef] [PubMed]

233. Sialve, B.; Bernet, N.; Bernard, O. Anaerobic digestion of microalgae as a necessary step to make microalgal biodiesel sustainable. Biotechnol. Adv. 2009, 27, 409-416. [CrossRef] [PubMed]

234. Yang, Z.; Guo, R.; Xu, X.; Fan, X.; Luo, S. Hydrogen and methane production from lipid-extracted microalgal biomass residues. Int. J. Hydrog. Energy 2011, 36, 3465-3470. [CrossRef]

235. Ma, J.; Duong, T.H.; Smits, M.; Verstraete, W.; Carballa, M. Enhanced biomethanation of kitchen waste by different pre-treatments. Bioresour. Technol. 2011, 102, 592-599. [CrossRef] [PubMed]

236. Elbeshbishy, E.; Nakhla, G. Comparative study of the effect of ultrasonication on the anaerobic biodegradability of food waste in single and two-stage systems. Bioresour. Technol. 2011, 102, 6449-6457. [CrossRef] [PubMed]

237. Cesaro, A.; Naddeo, V.; Amodio, V.; Belgiorno, V. Enhanced biogas production from anaerobic codigestion of solid waste by sonolysis. Ultrason. Sonochem. 2012, 19, 596-600. [CrossRef] [PubMed]

238. Zhang, Z.; Zhang, L.; Zhou, Y.; Chen, J.; Liang, Y.; Wei, L. Pilot-scale operation of enhanced anaerobic digestion of nutrient-deficient municipal sludge by ultrasonic pretreatment and co-digestion of kitchen garbage. J. Environ. Chem. Eng. 2013, 1, 73-78. [CrossRef]

239. López Torres, M.; Espinosa Lloréns, M. del C. Effect of alkaline pretreatment on anaerobic digestion of solid wastes. Waste Manag. 2008, 28, 2229-2234. [CrossRef] [PubMed] 
240. Li, Y.; Jin, Y. Effects of thermal pretreatment on acidification phase during two-phase batch anaerobic digestion of kitchen waste. Renew. Energy 2015, 77, 550-557. [CrossRef]

241. Ariunbaatar, J.; Panico, A.; Esposito, G.; Pirozzi, F.; Lens, P.N.L. Pretreatment methods to enhance anaerobic digestion of organic solid waste. Appl. Energy 2014, 123, 143-156. [CrossRef]

242. Shahriari, H.; Warith, M.; Hamoda, M.; Kennedy, K. Evaluation of single vs. staged mesophilic anaerobic digestion of kitchen waste with and without microwave pretreatment. J. Environ. Manag. 2013, 125, 74-84. [CrossRef] [PubMed]

243. Gonzales, H.B.; Takyu, K.; Sakashita, H.; Nakano, Y.; Nishijima, W.; Okada, M. Biological solubilization and mineralization as novel approach for the pretreatment of food waste. Chemosphere 2005, 58, 57-63. [CrossRef] [PubMed]

244. Fdez.-Güelfo, L.A.; Álvarez-Gallego, C.; Sales Márquez, D.; Romero García, L.I. The effect of different pretreatments on biomethanation kinetics of industrial Organic Fraction of Municipal Solid Wastes (OFMSW). Chem. Eng. J. 2011, 171, 411-417. [CrossRef]

245. Lim, J.W.; Wang, J.-Y. Enhanced hydrolysis and methane yield by applying microaeration pretreatment to the anaerobic co-digestion of brown water and food waste. Waste Manag. 2013, 33, 813-819. [CrossRef] [PubMed]

246. Liu, D.; Liu, D.; Zeng, R.J.; Angelidaki, I. Hydrogen and methane production from household solid waste in the two-stage fermentation process. Water Res. 2006, 40, 2230-2236. [CrossRef] [PubMed]

247. Del Borghi, A.; Converti, A.; Palazzi, E.; Del Borghi, M. Hydrolysis and thermophilic anaerobic digestion of sewage sludge and organic fraction of municipal solid waste. Bioprocess Eng. 1999, 20, 553. [CrossRef]

248. Vavouraki, A.I.; Angelis, E.M.; Kornaros, M. Optimization of thermo-chemical hydrolysis of kitchen wastes. Waste Manag. 2013, 33, 740-745. [CrossRef] [PubMed]

249. Peng, L.; Bao, M.; Wang, Q.; Wang, F.; Su, H. The anaerobic digestion of biologically and physicochemically pretreated oily wastewater. Bioresour. Technol. 2014, 151, 236-243. [CrossRef] [PubMed]

250. Elliott, A.; Mahmood, T. Pretreatment technologies for advancing anaerobic digestion of pulp and paper biotreatment residues. Water Res. 2007, 41, 4273-4286. [CrossRef] [PubMed]

251. Patinvoh, R.J.; Osadolor, O.A.; Chandolias, K.; Sárvári Horváth, I.; Taherzadeh, M.J. Innovative pretreatment strategies for biogas production. Bioresour. Technol. 2017, 224, 13-24. [CrossRef] [PubMed]

252. Johnson, D.K.; Elander, R.T. Pretreatments for Enhanced Digestibility of Feedstocks. In Biomass Recalcitrance; Himmel, M.E., Ed.; Blackwell Publishing Ltd.: Oxford, UK, 2008; pp. 436-453. ISBN 978-1-4443-0541-8.

253. Kim, Y.-K.; Kwak, M.-S.; Lee, S.-B.; Lee, W.H.; Choi, J.-W. Effects of Pretreatments on Thermophilic Aerobic Digestion. J. Environ. Eng. 2002, 128, 755-763. [CrossRef]

254. Appels, L.; Baeyens, J.; Degrève, J.; Dewil, R. Principles and potential of the anaerobic digestion of waste-activated sludge. Prog. Energy Combust. Sci. 2008, 34, 755-781. [CrossRef]

255. Wang, D.; Ai, P.; Yu, L.; Tan, Z.; Zhang, Y. Comparing the hydrolysis and biogas production performance of alkali and acid pretreatments of rice straw using two-stage anaerobic fermentation. Biosyst. Eng. 2015, 132, 47-55. [CrossRef]

256. Yang, D.; Wei, S.J.; Wen, Q.M.; Zhang, X.J. Comparison of Pretreatments for Lignocellulosic Biomass. Adv. Mater. Res. 2014, 1008-1009, 111-115. [CrossRef]

257. Eskicioglu, C.; Kennedy, K.J.; Droste, R.L. Characterization of soluble organic matter of waste activated sludge before and after thermal pretreatment. Water Res. 2006, 40, 3725-3736. [CrossRef] [PubMed]

258. Prorot, A.; Julien, L.; Christophe, D.; Patrick, L. Sludge disintegration during heat treatment at low temperature: A better understanding of involved mechanisms with a multiparametric approach. Biochem. Eng. J. 2011, 54, 178-184. [CrossRef]

259. Ariunbaatar, J.; Panico, A.; Frunzo, L.; Esposito, G.; Lens, P.N.L.; Pirozzi, F. Enhanced anaerobic digestion of food waste by thermal and ozonation pretreatment methods. J. Environ. Manag. 2014, 146, 142-149. [CrossRef] [PubMed]

260. Montgomery, L.F.; Bochman, G. Pretreatment of Feedstock for Enhanced Biogas Production; IEA Bioenergy: Paris, France, 2014; pp. 1-20.

261. Carlsson, M.; Lagerkvist, A.; Morgan-Sagastume, F. The effects of substrate pre-treatment on anaerobic digestion systems: A review. Waste Manag. 2012, 32, 1634-1650. [CrossRef] [PubMed]

262. Deublein, D.; Steinhauser, A. Biogas from Waste and Renewable Resources: An introduction; John Wiley \& Sons: Hoboken, NJ, USA, 2011. 
263. Ferraro, A.; Dottorini, G.; Massini, G.; Mazzurco Miritana, V.; Signorini, A.; Lembo, G.; Fabbricino, M. Combined bioaugmentation with anaerobic ruminal fungi and fermentative bacteria to enhance biogas production from wheat straw and mushroom spent straw. Bioresour. Technol. 2018, 260, 364-373. [CrossRef] [PubMed]

264. Morris, J.; Matthews, H.S.; Morawski, C. Review and meta-analysis of 82 studies on end-of-life management methods for source separated organics. Waste Manag. 2013, 33, 545-551. [CrossRef] [PubMed]

265. Vasco-Correa, J.; Khanal, S.; Manandhar, A.; Shah, A. Anaerobic digestion for bioenergy production: Global status, environmental and techno-economic implications, and government policies. Bioresour. Technol. 2018, 247, 1015-1026. [CrossRef] [PubMed]

266. Caine, M. Biogas Flares: State of the Art and Market Review, Topic report of the IEA Bioenergy Agreement Task 24-. Biological Conversion of Municipal Solid Waste; AEA Technology Environment: Oxfordshire, UK, 2000.

267. Yoshida, H.; Gable, J.J.; Park, J.K. Evaluation of organic waste diversion alternatives for greenhouse gas reduction. Resour. Conserv. Recycl. 2012, 60,1-9. [CrossRef]

268. Börjesson, P.; Berglund, M. Environmental systems analysis of biogas systems-Part II: The environmental impact of replacing various reference systems. Biomass Bioenergy 2007, 31, 326-344. [CrossRef]

269. Kirkeby, J.T.; Birgisdottir, H.; Hansen, T.L.; Christensen, T.H.; Bhander, G.S.; Hauschild, M. Evaluation of environmental impacts from municipal solid waste management in the municipality of Aarhus, Denmark (EASEWASTE). Waste Manag. Res. 2006, 24, 16-26. [CrossRef] [PubMed]

270. Woon, K.S.; Lo, I.M.C.; Chiu, S.L.H.; Yan, D.Y.S. Environmental assessment of food waste valorization in producing biogas for various types of energy use based on LCA approach. Waste Manag. 2016, 50, 290-299. [CrossRef] [PubMed]

271. Evangelisti, S.; Lettieri, P.; Borello, D.; Clift, R. Life cycle assessment of energy from waste via anaerobic digestion: A UK case study. Waste Manag. 2014, 34, 226-237. [CrossRef] [PubMed]

272. Güereca, L.P.; Gassó, S.; Baldasano, J.M.; Jiménez-Guerrero, P. Life cycle assessment of two biowaste management systems for Barcelona, Spain. Resour. Conserv. Recycl. 2006, 49, 32-48. [CrossRef]

273. Righi, S.; Oliviero, L.; Pedrini, M.; Buscaroli, A.; Della Casa, C. Life Cycle Assessment of management systems for sewage sludge and food waste: Centralized and decentralized approaches. J. Clean. Prod. 2013, 44, 8-17. [CrossRef]

274. Seo, S.; Aramaki, T.; Hwang, Y.; Hanaki, K. Environmental Impact of Solid Waste Treatment Methods in Korea. J. Environ. Eng. 2004, 130, 81-89. [CrossRef]

275. Eriksson, M.; Strid, I.; Hansson, P.-A. Carbon footprint of food waste management options in the waste hierarchy-A Swedish case study. J. Clean. Prod. 2015, 93, 115-125. [CrossRef] 